\title{
Vascular biology of uterine fibroids: connecting fibroids and vascular disorders
}

\author{
Gregory W Kirschen ${ }^{1, *}$, Abdelrahman AIAshqar ${ }^{1,2, *}$, Mariko Miyashita-Ishiwata1, \\ Lauren Reschke ${ }^{1}$, Malak El Sabeh ${ }^{1}$ and Mostafa A Borahay $\mathbb{B D}^{1}$ \\ ${ }^{1}$ Department of Gynecology and Obstetrics, Johns Hopkins University, Baltimore, Maryland, USA and ${ }^{2}$ Department \\ of Obstetrics and Gynecology, Kuwait University, Kuwait City, Kuwait
}

Correspondence should be addressed to G W Kirschen; Email: gkirsch7@jh.edu

*(G W Kirschen and A AlAshqar contributed equally to this work)

\begin{abstract}
Fibroids are benign tumors caused by the proliferation of myometrial smooth muscle cells in the uterus that can lead to symptoms such as abdominal pain, constipation, urinary retention, and infertility. While traditionally thought of as a disease process intrinsic to the uterus, accumulating evidence suggests that fibroid growth may be linked with the systemic vasculature system, although cell-intrinsic factors are certainly of principal importance in their inception. Fibroids are associated with essential hypertension and preeclampsia, as well as atherosclerosis, for reasons that are becoming increasingly elucidated. Factors such as the renin-angiotensinaldosterone system, estrogen, and endothelial dysfunction all likely play a role in fibroid pathogenesis. In this review, we lay out a framework for reconceptualizing fibroids as a systemic vascular disorder, and discuss how pharmaceutical agents and other interventions targeting the vasculature may aid in the novel treatment of fibroids.

Reproduction (2021) 162 R1-R18
\end{abstract}

\section{Introduction}

Uterine leiomyomas (commonly referred to as 'fibroids') are the most common benign neoplasm of the female reproductive tract, present in up to $77 \%$ of reproductiveage women (Cramer \& Patel 1990, Okolo 2008). While fibroids may be clinically silent, many women with fibroids suffer from heavy menstrual bleeding, chronic pelvic pain, dyspareunia, dysmenorrhea, bulk symptoms (e.g. urinary hesitancy, constipation), or pregnancy difficulties that negatively impact the quality of life (Zimmermann et al. 2012, Zepiridis et al. 2016). Indeed, symptomatic fibroids are responsible for over 350,000 hospitalizations and the leading indication for hysterectomy in the United States (Wechter et al. 2011, Shahid et al. 2020).

Despite the prevalence and burden of the disease, the origins and pathogenesis of fibroids remain largely a mystery. Clues to possible driving factors for the development and propagation of fibroids have come from their risk factors. Epidemiological studies have demonstrated that genetic factors such as positive family history and hypertension portend an increased risk of fibroids, suggesting that these factors may influence vascular dysfunction and play a role in fibroid pathogenesis (Radin et al. 2012, Wise \& LaughlinTommaso 2016, Stewart et al. 2017).
Curiously, within the realm of hypertensive disorders, preeclampsia, a hypertensive and vascular disorder of pregnancy, has been positively associated with fibroid occurrence (Roberts et al. 1999, Pan et al. 2019). Further, polymorphisms in genes regulating vascular tone and arterial blood flow including the angiotensinconverting enzyme (ACE) and angiotensin receptor have been associated with fibroids, also suggesting a possible underlying pathological link (Gomaa et al. 2015, Keshavarzi et al. 2019).

It is of course worth acknowledging the progress that has been made in the fundamental understanding of fibroid biology. Fibroid development is a multistep process involving uterine smooth muscle stem cell alterations in estrogen, progesterone and Wnt signaling that lead to expansion of this cell population, followed by fibroblast and vascular smooth muscle cell recruitment and ECM deposition, leading to clinically significant fibroids (Stewart et al. 2016). Genetic changes causally related to the development of approximately $90 \%$ of fibroids include alterations in signaling involving the mediator subcomplex 12 (MED-12) and high mobility group protein (HMGA) 1 and 2 genes. MED12 is a highly conserved gene on the $X$ chromosome that codes for a transcription factor regulating a multitude of genes pertinent to cell cycling/proliferation, including $W N T$, CCND1, AXIN2, and MYC (Makinen et al. 2011). While 
MED12 mutation does not vary with patient age and race but does correlate with smaller tumors and more numerous tumors (He et al. 2021).

HMGA1 and the closely related HMGA2 genes code for proteins involved in the regulation of chromatin architecture and transcription modulation, globally influencing cell cycle kinetics, differentiation and proliferation particularly of stem cell populations (Chieffi et al. 2002). Rearrangements leading to overexpression of HMGA1 and HMGA2 mRNA have been observed in fibroids, likely influencing tumor growth via direct promotion of proliferation and indirectly via upregulation of angiogenesis (Medeiros et al. 2007, Nezhad et al. 2010, Ferrero 2020, Li et al. 2020).

Apart from direct genetic mutations, epigenetic modifications and non-coding RNAs have been implicated in fibroid biology. Early life events, including environmental exposures in utero and in the prepubescent period (particularly to estrogens, genistein and diethylstilbestrol), likely alter epigenetic programs in uterine stem cell populations, reflected in differences in DNA methylation between fibroid cells and adjacent normal myometrium, predisposing to fibroid development later in life (Bulun 2013, Elkafas et al. 2017, McWilliams \& Chennathukuzhi 2017). Further, alterations in miRNA, single-stranded non-coding RNA molecules, play a regulatory role in steroid-induced cellular processes important in fibroid biology via cytokine/chemokine mediators, including proliferation, apoptosis, ECM deposition, MMP activity, and autophagy (Bulun 2013, Ciavattini et al. 2013, McWilliams \& Chennathukuzhi 2017, Ciebiera et al. 2020).

Estradiol and progesterone are also synergistically involved in fibroid development. Estradiol stimulates estrogen receptors on uterine fibroblasts and promotes fibroblast proliferation and extracellular membrane production through fibroblast activation protein (FAP), MAP kinase activation, and activation of the PI3KAkt-mTOR pathway in vitro (Luo et al. 2014, Borahay et al. 2017). Progesterone, on the other hand, activates progesterone receptors on fibroid cells which further activates the PI3K-Akt pathway, promoting fibroid cell survival in vitro (Hoekstra et al. 2009). In fact, inhibition of this pathway by gonadotropin receptor hormone $(\mathrm{GnRH})$ therapy triggers fibroid cell apoptosis and is one modality of treatment for symptomatic fibroids (Yamada et al. 2004). On the other hand, combined oral contraceptive pills (OCPs), which contain estrogen and progestin, can reduce fibroid-related abnormal uterine bleeding, but they do so via a different mechanism, that is, by stabilizing and decidualizing the endometrium (Sayed et al. 2011).

In this article, we will refer to two related but distinct biological processes - vasculogenesis and angiogenesis. Vasculogenesis, or the de novo formation of blood vessels from pluripotent mesenchymal cells, is a developmental process that occurs in the uterus during placentation which undergoes remodeling as gestation advances (Demir et al. 2006, Tal et al. 2019). Villous hemangiogenic cells develop into angioblasts which in turn differentiate into endothelial cells, initiating placental vasculogenesis (Demir et al. 2006). As opposed to vasculogenesis, angiogenesis is the sprouting of new vessels from preexisting vasculature. Both occur in the context of uterine biology and fibroid formation.

Given new developments in fibroid research, we lay out accumulating evidence in this article that fibroids may, at least in some circumstances, be part of a vascular disease process.

\section{Overview of uterine vasculogenesis and angiogenesis}

Once believed to occur solely through angiogenesis, uterine remodeling during pregnancy is now thought to also have a vasculogenic component (Tal et al. 2019). In pregnant mice, bone marrow-derived cells (BMDCs), namely endothelial progenitor cells (EPCs), have indeed been shown to participate in decidual growth and uterine vasculogenesis, aside from that seen in placentation (Tal et al. 2019). From a pathological perspective, vasculogenesis is essential for tumor growth and maintenance, particularly when angiogenesis is blocked (Brown 2014). While vasculogenesis in uterine fibroids has yet to be definitively identified, these tumors have shown the capability to secrete CXCL12, a chemokine that recruits BMDCs, perhaps facilitating fibroid growth through engrafting stem cells into the tumor (Moridi et al. 2020). Nevertheless, uterine vasculogenesis remains a largely unexplored avenue and whether BDMCs contribute to uterine fibroid vasculogenesis per se remains to be understood.

Angiogenesis, by contrast, has long been known to occur in the uterus in physiological and pathological settings (Zygmunt et al. 2003). Given the dynamic nature of the endometrium and the increasing demand for blood supply throughout pregnancy, angiogenesis is deemed fundamental to sustain uterine physiology and establish fetal viability (Zygmunt et al. 2003, Demir et al. 2010). In addition to its contribution to the development of tumors at large, dysregulated angiogenesis has been reportedly noted in a wide array of uterine pathologies, including placenta accreta spectrum, abnormal uterine bleeding, as well as the focus of this review, uterine fibroids (Jaffe 2000, Tseng \& Chou 2006, Tal \& Segars 2014). Uterine fibroids have a well-vascularized capsule yet a hypovascular core, a unique demarcation that has led the scientists to propose the presence of an inherent angiogenic defect (Carmeliet 2003, Tal \& Segars 2014). Our knowledge of the exact culprits behind these observations is limited and further understanding of the possible mechanisms that underlie the vascular pathobiology of uterine fibroids is crucial. 


\section{Fibroid composition and vasculature}

\section{Fibroid composition}

Fibroids are characterized by benign monoclonal proliferation of smooth muscle cells and fibroblasts, with extensive deposition of extracellular matrix components (Holdsworth-Carson et al. 2014). The clonality of these tumors implies an internal (oncogenic) driver of proliferation. At the same time, it is possible that vascular changes may modulate this cell-intrinsic propensity of monoclonal proliferation leading to the initiation and growth of fibroids, as will be discussed further later. Fibroids are differentiated from leiomyosarcoma (malignant proliferation of smooth muscle cells) and from smooth muscle tumors of uncertain malignant potential (STUMP lesions) based on the mitotic index, degree of cellular atypia and necrosis (Watanabe \& Suzuki 2006, Bacanakgil et al. 2017). Fibroids have been posited to arise from an aberrant myometrial proliferative/ extracellular matrix (ECM) synthetic reparative response to vascular injury or ischemia (Flake et al. 2013). On an ultrastructural level, fibroid cells exhibit increased protein synthesis machinery (rough endoplasmic reticulum, free ribosomes, and Golgi apparatus) and contain fewer contractile elements as compared to normal myometrial cells (Flake et al. 2013).

Aside from their basic make-up, fibroids are dynamic in structure and activity in the early stage of their life cycle, contrary to what might be supposed based on static histological images. Indeed, fibroid development can be divided into four phases: differentiated based on collagen content (which increases as fibroids mature), myocyte proliferation (active in phases 1-3), collagen synthesis (active in phases 2 and 3), and involution (which has the highest collagen content) (Flake et al. 2013).

\section{Vascular supply}

Fibroids depend almost entirely upon the uterine arteries for recruitment of their blood supply, although the uterus additionally receives secondary blood supply from the ovarian arteries, which could theoretically feed a proximal fibroid. Fibroids develop a rich network of secondary branches and disrupt and enlarge the caliber and course of the uterine arteries (Pelage et al. 2005). Likewise, the uterine arteries of fibroid uteri have increased blood flow, lower resistance index and pulsatility index as compared to the uterine arteries from non-fibroid uteri (Kurjak et al. 1992). For instance, fibroids display ongoing blood flow in both systole and diastole, as well as a higher flow rate compared to the main uterine arteries, demonstrating a relentless demand for blood supply (Kurjak et al. 1992). Consistent with this finding, uterine blood flow rate also correlates positively with fibroid size (Alatas et al. 1997). By contrast, fibroids themselves are quite hypovascular at their cores and are supplied by small peripheral arteries via arterial plexuses, with few containing intrafibroid arteries (Pelage et al. 2005, Idowu \& Ibitoye 2018). The type of cell death that fibroids exhibit in response to lack of blood supply has been referred to as 'inanosis, ' or death due to nutritional deprivation, as fibroids typically lack the histological hallmarks of either necrosis or apoptosis (Flake et al. 2013). The vascular smooth muscle cells of vessels supplying the fibroids likewise can exhibit parallel features to the fibroid cells themselves. Thus, while fibroids constitute the product of monoclonal proliferation of a neoplastic cell, implying a cell-intrinsic process, the propensity of such cells to develop and grow into a fibroid may be modulated by vascular factors such as blood flow patterns and vascular-derived signals.

\section{Clinical correlates}

\section{Hypertension}

The association between uterine fibroids and hypertension has been extensively addressed in the literature. Several studies have found a significant positive correlation between the two disorders (Luoto et al. 2001, Haan et al. 2015, 2018), but causality has not yet been successfully established. A prospective study has examined the relation between diastolic blood pressure and the incidence of clinically detected uterine fibroids and detected a 10 and $8 \%$ rise in fibroid risk for each $10 \mathrm{mmHg}$ increase in diastolic blood pressure among users and nonusers of antihypertensives, respectively (Boynton-Jarrett et al. 2005). In considering the relationship between hypertension and fibroids, it is important to consider potential confounding factors. In fact, one study found that the association between hypertension and fibroids persisted even after adjusting for obesity, African ancestry, hormonal contraceptive use, parity, postmenopausal status, fasting plasma cholesterol and fasting plasma glucose (except for diabetes), with odds ratios between 1.80 and 1.90 (Haan et al. 2018).

On the other hand, hypertension results in smooth muscle cell injury through mechanical shear stress, perhaps involving the uterine vasculature that induces myomatous proliferation and fibroid genesis (Fig. 1) (Humphrey 2008). Elevated blood pressure also induces proinflammatory milieus and upregulates ECM synthesis, in part through the action of TGF- $\beta$, which has been seen to activate fibroblasts in rats induced to have hypertension (Kuwahara et al. 2002, Boynton-Jarrett et al. 2005). Another mediator possibly implicated in the association between hypertension and uterine fibroids is the enzyme creatine kinase (CK) (Hoag et al. 1980, Brewster et al. 2006), which has been shown to induce vascular and uterine smooth muscle cell proliferation by replenishing ATP for vascular contractility and trophic processes (Karamat et al. 2014, Haan et al. 2018). Indeed, higher levels of CK have been detected in leiomyomatous tissues compared to healthy myometrium (Hoag et al. 1980). The consistent evidence of the correlation between hypertension and uterine fibroids 


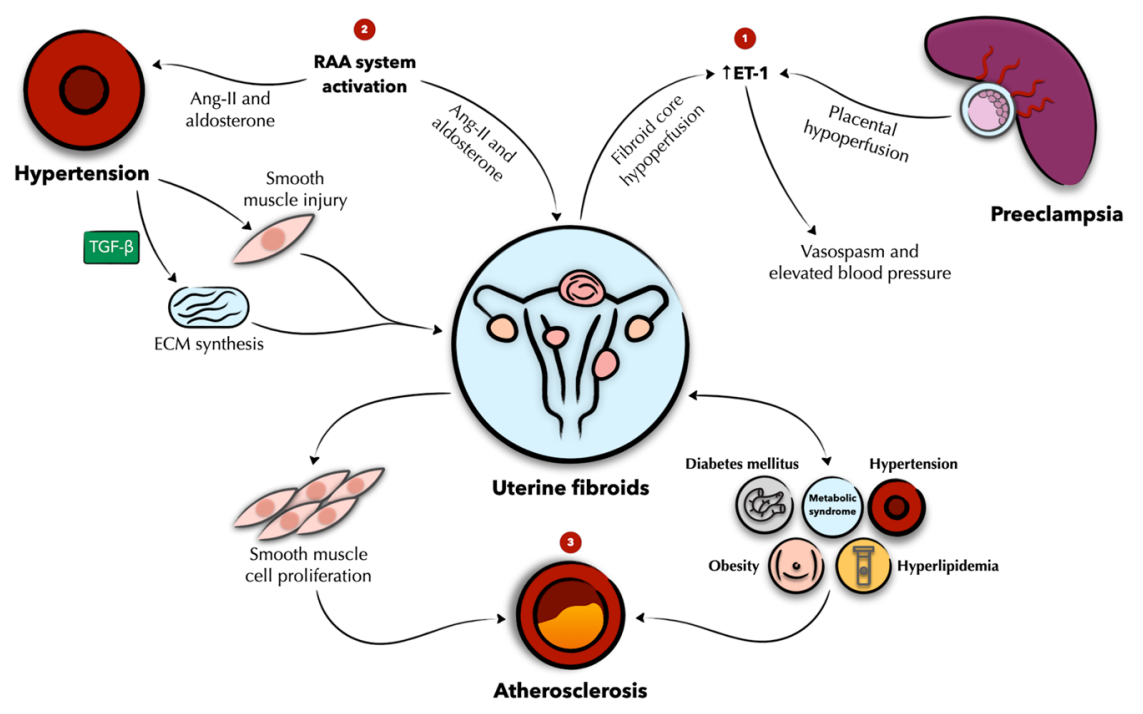

Figure 1 Schematic presentation of the association of uterine fibroids with systemic vascular disorders. (1) Similar to preeclampsia, the association of uterine fibroids with hypertension may be mediated by ET-1. (2) RAA system activation and hypertensionmediated smooth muscle injury and ECM upregulation may explain the association between uterine fibroids and hypertension. (3). Uterine fibroids and atherosclerosis are resemblant in terms of pathological features and associated risk factors. Angiotensin, Ang; endothelin-1, ET-1; extracellular matrix, ECM; renin-angiotensin-aldosterone, RAA; transforming growth factor $\beta$, TGF- $\beta$.

raises the prospect, once again, of vascular involvement in fibroid pathobiology. Although speculations largely predominate the underlying pathophysiology of this association, uterine fibroids may now be perceived as a marker for hypertension and that women with fibroids may start to be screened for elevated blood pressure and vice versa (AlAshqar et al. 2019). Not only this approach may expedite the detection of a largely asymptomatic disease such as hypertension but also decrease the risk of cardiovascular outcomes in the long run (LaughlinTommaso et al. 2019).

\section{Atherosclerosis}

An accumulating body of evidence has supported the notion that uterine fibroids and atherosclerosis bear pathophysiological resemblance (Fig. 1). This hypothesis is reinforced by several observations: (1) both atherosclerosis and uterine fibroids represent a pathological proliferative lesion of smooth muscle cells; (2) similar to fibroids, atheromatous plaques may have a monoclonal origin; and (3) both lesions can eventually fibrose and calcify (Benditt \& Benditt 1973, Moss \& Benditt 1975). In each case, the production of reactive oxygen species (ROS) leads to stimulation of fibroid cell or vascular smooth muscle cells by platelet-derived growth factor (PDGF), leading to enhanced the MAP kinase mitogenic signaling, stimulating smooth muscle cell proliferation (Shimizu et al. 2009, Mesquita et al. 2010). From a clinical perspective, while some studies have failed to detect an association between subclinical cardiovascular disease and uterine fibroids (LaughlinTommaso et al. 2019), others demonstrated that indicators of atherosclerosis are more prevalent among women with uterine fibroids. For instance, a populationbased longitudinal study found an independent positive association between fibroids and LDL and triglyceride levels (Uimari et al. 2016). As stated previously, Aksoy et al. concluded that cIMT, a surrogate marker for early atherosclerosis, is significantly elevated in women with fibroids, which may allow for its use as a screening measure for subclinical cardiovascular disease in this population (Aksoy et al. 2014).

Moreover, a case-control study of Chinese women investigated the association of atherogenic risk factors with uterine fibroids and concluded that higher anklebrachial index $(\mathrm{ABI})$ readings, another marker of early atherosclerosis, are associated with increased odds of uterine fibroids. Our group has also previously reviewed the various mechanisms underlying the association between uterine fibroids and cardiometabolic risk factors (Fig. 1), lending further support to the presence of shared pathophysiology between fibroids and atherosclerosis (AlAshqar et al. 2019). In fact, cardiometabolic risk factors, such as advanced age and hypertension, have been shown to significantly correlate with uterine artery atherosclerosis (Crawford et al. 1997), but whether the latter may serve as a marker for atherosclerosis in other vascular beds or is a potential culprit in fibroid initiation and growth is yet to be investigated. Nevertheless, our growing knowledge of the association between atherosclerotic vascular disease and uterine fibroids will pave our way to a better understanding of the vascular involvement in uterine fibroids.

\section{Preeclampsia}

Although scarce, evidence of an association between uterine fibroids and preeclampsia has been reported in the literature. A case-control study by Pan et al. has documented uterine fibroids as a significant pre-existing medical risk factor for preeclampsia (Pan et al. 2019). Further, a study by Roberts et al. concluded that multiple fibroids imply a higher risk of preeclampsia compared to a single fibroid, which the authors attributed to the disruption of trophoblastic invasion of spiral arteries caused 
by the expanding fibroid (Roberts et al. 1999). Although plausible, there may be more to the role of fibroids in preeclampsia occurrence than a mere mechanical effect. As previously discussed, mediators, such as ET-1, ghrelin, and sHLA-G, may represent common grounds on which vascular dysfunction may contribute to uterine fibroids and preeclampsia and where research efforts can be therefore guided in the future.

Intriguingly, uterine natural killer (uNK) cell involvement may be a potential mechanism that links uterine fibroids to preeclampsia. For example, altered numbers of UNK cells in the endometrium of women with uterine fibroid has been hypothesized to decrease fertility and promote aberrant vascular development, possibly leading to higher risk of recurrent miscarriages and implantation failure (Quenby et al. 2009, Lash \& Bulmer 2011). On the other hand, studies quantifying decidual uNK cells in preeclamptic women have shown mixed and inconsistent results that may be better overcome by conducting the analysis during pregnancy than after delivery (Bachmayer et al. 2006, Lash \& Bulmer 2011). Nevertheless, given the increasingly recognized role of uNK in spiral artery remodeling and vascular wall invasion by the extravillous trophoblast (Lash \& Bulmer 2011), the notion that aberrant uNK cell numbers may contribute to preeclampsia is still valid and a hypothesis that can be further investigated.

\section{Potential biomarkers implicated in the vascular pathobiology of uterine fibroids}

A plethora of circulating markers have been reported in the literature to have a differential expression in women with and without uterine fibroids, a few of which may be potentially involved in the vascular aberrancies seen in these tumors.

\section{Prolactin}

Prolactin has been demonstrated to be expressed by uterine endometrial and myometrial tissues and to a greater extent by uterine fibroids (Walters et al. 1983, Daly et al. 1984, Rein et al. 1990). It remains unclear as to whether fibroid-secreted prolactin contributes to the development of the tumor itself or is rather a mere marker of tumor growth. However, it was shown that the addition of prolactin-neutralizing antibodies to myometrial and fibroid cell cultures halts cellular proliferation, suggesting that prolactin may indeed behave as a growth factor in an autocrine or paracrine fashion (Nowak et al. 1999). In addition, prolactin has been found to have mitogenic properties invascularsmooth muscle cellsthrough a protein kinase C-mediated mechanism, predisposing to vascular smooth muscle cell hyperplasia, a feature reminiscent of what happens in hypertension and atherosclerosis (Sauro \& Zorn 1991). These findings lend further support to the vascular theory of fibroid pathogenesis and may link their occurrence to systemic vascular disorders. Although evidence suggests that elevated serum prolactin levels are observed in patients with uterine fibroids (Baban 2009), other common causes of hyperprolactinemia including the presence of an asymptomatic prolactinoma, were not taken into account. Hence, while such results may show promise in the potential use of prolactin as a fibroid marker, further experimental studies are needed to validate this observation.

\section{Ghrelin}

Ghrelin, a peptide hormone involved in energy regulation, is another marker that has been found to be associated with uterine fibroids. A study has concluded that patients with symptomatic fibroids have significantly higher active ghrelin and active to total ghrelin ratio compared to controls matched for BMI. However, as levels largely overlap between cases and controls, the use of ghrelin as a biomarker may not be possible (Markowska et al. 2009). In addition, although it was shown that ghrelin is produced and processed in the human myometrium (O'Brien et al. 2010), its role in uterine fibroids per se is yet to be elucidated. Within the context of vascular dysfunction, serum ghrelin level has been positively correlated with the severity of preeclampsia but negatively so with uterine artery Doppler index values and systolic and diastolic blood pressures (Erol et al. 2016). Although these observations may seem conflicting, a few mechanisms have been suggested to explain the increase in serum ghrelin in preeclampsia, possibly explaining its increased levels in uterine fibroids. Given the body of evidence that suggests a protective effect of ghrelin against hypertension, atherosclerosis, and cardiovascular disease (Zhang et al. 2010), the increase in ghrelin in preeclamptic women may be a compensatory mechanism to derangements in some mediators involved in the disease (Aydin et al. 2008, Erol et al. 2016). In addition, ghrelin may manifest inhibitory actions during early pregnancy that interfere with proper embryo implantation on the one hand (Delgado \& Ganea 2008) and angiogenic actions that induce aberrant vascular remodeling on the other hand, both of which may increase the risk of preeclampsia (Zaniolo et al. 2011, Erol et al. 2016). Nevertheless, these mechanisms are largely speculative and further in vivo and in vitro studies are needed to confirm these speculations.

\section{Vascular endothelial growth factor}

Vascular endothelial growth factor (VEGF), a master regulator of neovascularization, has been found to be elevated in patients with uterine fibroids compared to those without, with levels declining after hysterectomy (Chen et al. 2005). This comes in line with previous work showing the uterus' capability of VEGF production 
(Torry et al. 1996, Agrawal et al. 2000), but this also suggests that VEGF expression may be more pronounced in uterine pathology, including fibroids. Whereas some studies detected higher VEGF expression in fibroids compared to normal myometrium (Hague et al. 2000, Gentry et al. 2001), others concluded no differential expression of VEGF mRNA and VEGF protein between myometrial and fibroid smooth muscle cells (HarrisonWoolrych et al. 1995), emphasizing the need for more consistent data in this regard. Despite the lack of evidence of its growth-promoting actions in smooth muscle cells (Ferrara et al. 1992), VEGF may contribute to uterine fibroids in a mechanism that is not necessarily mitogenic. VEGF stimulates angiogenesis and increases vascular permeability, potentially facilitating tumor growth, and induces endothelial cell proliferation, indirectly upregulating other growth factors. For example, VEGF can liberate basic fibroblast growth factor (bFGF) from moieties in the extracellular matrix, which in turn has mitogenic properties in smooth muscle cells (Jonca et al. 1997, Flake et al. 2003). Despite the interest in this growth factor as a potential culprit of abnormal vascular function in uterine fibroids, it may not serve as an effective biomarker as it does not predict fibroid development (Chen et al. 2005).

\section{Hematopoietic growth factors}

Hematopoietic growth factors (HGFs), namely macrophage-colony stimulating factor (M-CSF) and granulocyte-colony stimulating factor (G-CSF), have been evaluated as potential candidate markers for uterine fibroids. Both markers are increased in patients with uterine fibroids compared to controls and can be used to distinguish between endometrial cancer and fibroids, particularly when used with CA125 (Lawicki et al. 2010). While HGFs may not have direct mitogenic actions on smooth muscle cells, they have been shown to promote tumor angiogenesis (Ribatti \& Tamma 2019). Indeed, HGFs have been demonstrated to induce endothelial proliferation and migration both in vivo and in vitro (Bussolino et al. 1989, 1991). In contrast, endothelial cells exposed to VEGF manifested increased release of HGFs by bone marrow endothelial cells (Bautz et al. 2000), highlighting a reciprocal association between HGFs and key angiogenic factors that may or may not occur on pathophysiological grounds in uterine fibroids.

\section{Tumor necrosis factor $\alpha$}

A growing body of evidence now shows that tumor necrosis factor $\alpha$ (TNF- $\alpha)$ may play a particularly notable role in the development of uterine fibroids. In vitro studies have demonstrated increased proliferation of human fibroid cells and expression of anti-apoptotic markers when exposed to TNF- $\alpha$. In addition, this pro-proliferative effect has been reversed upon adding anti-TNF- $\alpha$ antibodies (Nair \& Al-Hendy 2011). Further, women with uterine fibroids are found to have an approximately twofold increase in serum TNF- $\alpha$ levels compared to controls, with levels increasing with fibroid size (Ciebiera et al. 2018a). These findings may suggest the potential use of TNF- $\alpha$ as a marker for uterine fibroids, using a level cutoff point that may also help to distinguish fibroids from STUMP lesions and leiomyosarcoma (Ciebiera et al. 2018b). Although the actions of TNF- $\alpha$ in fibroids appear to be tumorigenic, the literature has reported a role for TNF- $\alpha$ in vascular dysfunction elsewhere. For instance, TNF- $\alpha$ was shown to downregulate the production of nitric oxide (NO) via inhibition of endothelial $\mathrm{NO}$ synthase (eNOS), thereby impairing smooth muscle relaxation and inducing endothelial dysfunction (Zhang et al. 2009). This was further supported by the finding that TNF- $\alpha$ predisposes to endothelial dysfunction in animal models with diabetes and metabolic syndrome by means of reactive oxygen species production (Picchi et al. 2006, Lee et al. 2017a). Thus, given the existing evidence that uterine fibroids may be associated with cardiometabolic risk factors and atherosclerosis (AlAshqar et al. 2019), inflammation may contribute to vascular dysfunction in fibroids in a similar way to that seen in cardiometabolic risk factors.

\section{Soluble HLA G}

Soluble HLA G (sHLA-G), a human non-classical major histocompatibility complex molecule involved in immune regulation and expressed in the uterus, has been found to be statistically significantly higher in women with uterine fibroids compared to controls (Basta et al. 2009, Levy et al. 2013). In addition, it was found to be elevated in patients with systemic sclerosis, an autoimmune disorder with profound vascular involvement (Contini et al. 2018). Although not entirely understood, sHLA-G was suggested to contribute to systemic sclerosis pathogenesis through its interaction with transforming growth factor $\beta$ (TGFB1) (Contini et al. 2018). It is wellestablished that TGB1 plays a significant role in the pathobiology of uterine fibroids through downstream signaling with Smad and the PI3K-AKT-mTOR and MEK-ERK pathways (Ciebiera et al. 2017) but whether sHLA-G interacts with TGFB1 or has any pathogenic role in uterine fibroids has yet to be determined. From another perspective, it is worth noting that sHLA-G serves to promote proinflammatory cytokine secretion in the placenta, facilitating trophoblast migration and vascular remodeling (Dahl et al. 2014). Although controversial, studies linked HLA-G genotypes and aberrant HLA-G protein expression with preeclampsia, with most studies showing reduced serum levels in preeclamptic women (Hara et al. 1996, Dahl et al. 2014). This points to the potential involvement of sHLA-G in vascular pathology, but further investigation is warranted regarding its role in uterine fibroids. 


\section{Lactate dehydrogenase $A$}

Lactate dehydrogenase A (LDHA) is another blood marker that exhibits significantly higher levels in patients with uterine fibroids vs those without (Koukourakis et al. 2009). However, as LDHA can also be elevated in patients with uterine sarcoma and endometrial cancer (Song et al. 2018), LDHA is difficult to interpret in patients with uterine masses, rendering it unhelpful as a fibroid biomarker (Koukourakis et al. 2009). Although its role in uterine fibroid development, if any, remains unexplored, LDHA has been implicated in vascular dysfunction. Upregulation of LDHA and glycolysis in vascular smooth muscle cells, stimulated by plateletderived growth factor (PDGF), promotes the proliferation and migration of these cells, perhaps predisposing to atherosclerosis (Kim et al. 2017). This observation may link the development of uterine fibroids to an element of local and systemic vascular dysfunction, but further experimental validation is needed.

\section{Cancer antigen 125}

Cancer antigen 125 (CA125), a marker best known for its association with ovarian cancer, can, in fact, be elevated in a variety of gynecologic and nongynecological disorders that produce peritoneal irritation, including, among many other entities, uterine fibroids (Juang et al. 2006, Levy et al. 2013). It is largely unknown whether CA125 is actively involved in the pathogenesis of uterine fibroids or is passively secreted by the tumor instead. Nevertheless, a link between CA125 and vascular dysfunction has been reported in the literature. In patients with epithelial ovarian cancer, for example, intracystic VEGF levels were positively correlated with serum CA125 levels. This was hypothesized to occur due to VEGF-mediated enhancement of tumor angiogenesis and vascular permeability that leads to increased spillage of CA125 into the circulation (Candido Dos Reis et al. 2002). Although this may not suggest a pathogenic role for CA125 in uterine fibroids, it may point to similar vascular processes in the fibroid that may parallel the increase in serum CA125. The implications of CA125 in vascular pathology extend beyond gynecologic perspectives as its serum levels have been found to be correlated with carotid intimamedia thickness (cIMT) in patients with coronary artery disease (Sang et al. 2018). Intriguingly, cIMT has been found to be significantly higher in women with uterine fibroids compared to those without, suggesting that fibroids may indeed share common etiopathogenic mechanisms with atherosclerotic vascular disease (Aksoy et al. 2014, AlAshqar et al. 2019). Although inflammation seems to underlie, at least in part, the increase in CA125 and vascular dysfunction (Sang et al. 2018), further evidence is needed to confirm the nature of this association.

\section{Molecular biology of abnormal vascular function in fibroids}

\section{Endothelin-1 (ET-1) and soluble Fms-like tyrosine kinase-1 (sFlt-1)}

The hypovascularity of fibroids creates a hypoxic microenvironment that serves as a positive feedback loop driving proliferation and neovascularization (Fig. 2). For instance, endothelin-1 (ET-1) is a potent vasoconstrictor peptide secreted by endothelial cells and fibroid smooth muscle cells in response to hypoxia. ET- 1 is elevated in the plasma of women with fibroids, compared to those without, and drives fibroid cell proliferation (Wallace et al. 2014, 2018). Blockade of $\mathrm{ET}_{\mathrm{A}}$ receptors on fibroid smooth muscle cells under both normoxic as well as hypoxic conditions leads to decreased proliferation of these cells, suggesting an autocrine function for ET-1 that helps drive fibroid growth (Wallace et al. 2018). Beyond promotion of fibroid cell division, ET-1 has been shown to have a direct angiogenic effect on endothelial cells and indirect effects via stimulation of vascular endothelial growth factor (VEGF) (Knowles et al. 2005). Intriguingly, ET-1 dysregulation has also been implicated in preeclampsia (Fig. 1). It has been postulated that abnormal placentation in the uterine wall in patients who will go on to develop preeclampsia leads to elevated circulating levels of anti-angiogenic factors such as soluble Fms-like tyrosine kinase-1 (sFlt-1), a VEGF decoy receptor that functionally inactivates VEGF and causes a rise in ET-1, likely through tissue hypoxia (Saleh et al. 2016). Indeed, sFlt-1 binds VEGF with tenfold greater affinity than native receptors, making sFlt-1 a VEGF sink and effectively enhancing ET-1 synthesis in response to hypoxia (Wallace et al. 2014). Circulating levels of sFlt- 1 in women with fibroids are increased by nearly $50 \%$ as compared to those without, suggesting the pathophysiological significance of this small molecule in vivo (Wallace et al. 2014).

Elevated ET-1, in turn, drives systemic vasoconstriction, vascular dysfunction, and elevated mean arterial pressure, all characteristics of preeclampsia (PossomatoVieira \& Khalil 2016). The fact that fibroids are also associated with elevated ET-1 levels and systemic hypertension suggests a possible unifying pathogenic link between these two disease entities that can be traced to abnormal uterine vascularity. Further evidence supporting this common underlying pathophysiology is the intriguing clinical association shown in several studies that smoking may be paradoxically protective against both fibroids and preeclampsia. It is puzzling that smoking seems to be directly related to atherosclerosis but inversely related to fibroid development. This can perhaps be partially explained through nicotinic effects on the balance of angiogenic factors, although this phenomenon remains controversial and poorly understood (Baron 1996, Parazzini et al. 1996, England \& Zhang 2007, Templeman et al. 2009, 


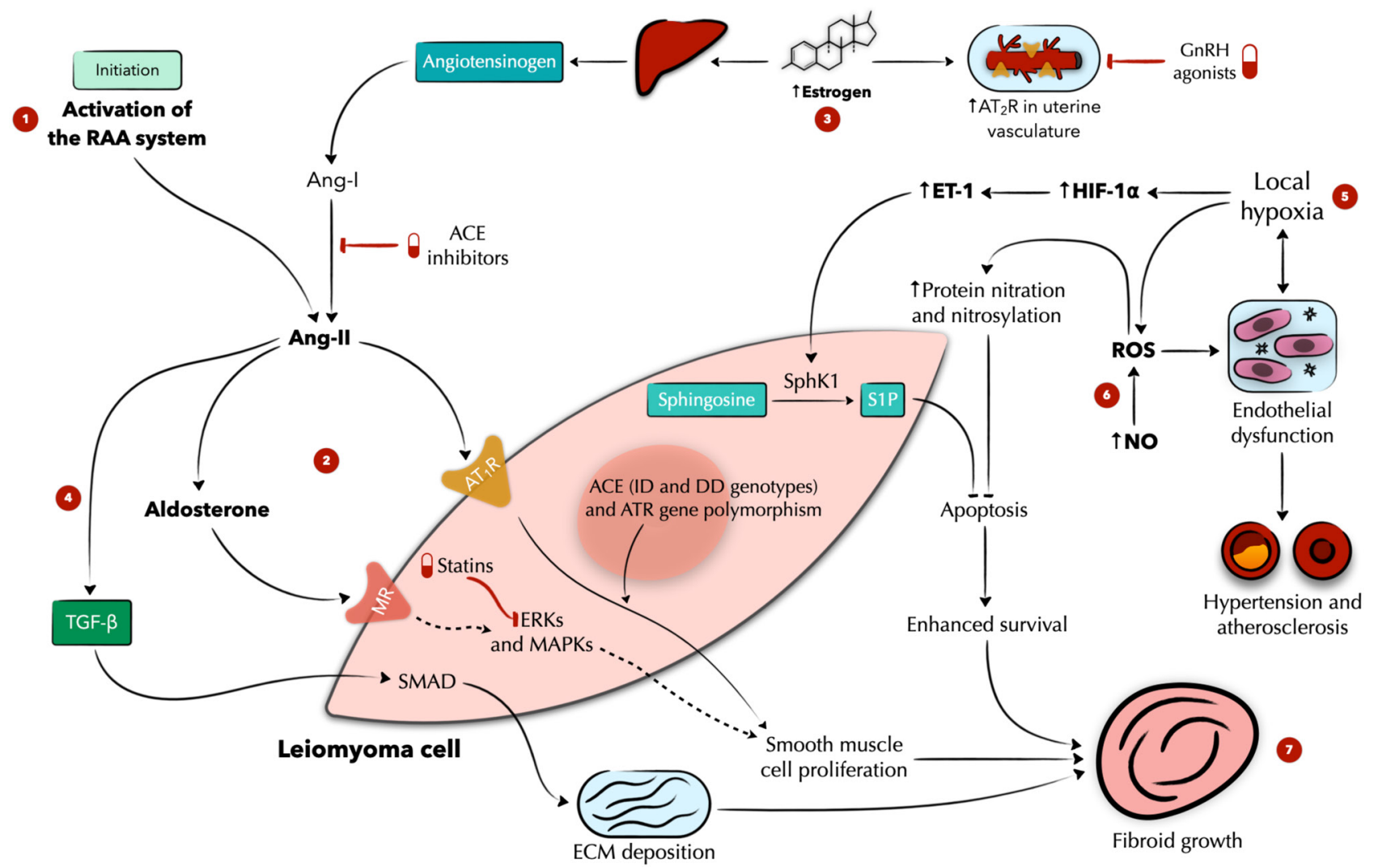

Figure 2 Schematic presentation of vascular dysfunction and vasoactive mediators involved in uterine fibroid pathogenesis. (1) Aberrant activation of the RAA system is implicated in fibroid cell proliferation through the actions of Ang-II and aldosterone. (2) The tumorigenic actions of Ang-II are potentiated via ACE and ATR gene polymorphisms whereas those of aldosterone may be mediated by MAPKs and ERKs. (3) Estrogen can augment the actions of the RAA system in fibroids by upregulating hepatic angiotensinogen production and $\mathrm{AT}_{2} \mathrm{R}$ expression in the uterine vasculature. (4) Ang-II may additionally upregulate TGFB1 expression and ECM synthesis. (5) Vascular dysfunction in uterine fibroids may create a local hypoxic milieu that upregulates HIF-1 $\alpha$, and in turn, ET-1 expression. In the fibroid cell, ET-1 activates the enzyme SphK1, promoting the conversion of sphingosine to S1P, which inhibits apoptotic cascades and enhances cell survival. (6) Increased basal NO induces ROS production, inhibition of apoptosis, endothelial dysfunction, and systemic vascular disorders. (7) Collectively, increased cellular proliferation, decreased apoptosis and enhanced ECM synthesis promote fibroid growth. Dashed lines denote hypothesized mechanisms. Angiotensin, Ang; angiotensin-converting enzyme, ACE; angiotensin receptor, ATR; endothelin-1, ET-1; extracellular matrix, ECM; extracellular regulated kinases, ERKs; gonadotrophi-releasing hormone, GnRH; hypoxia-inducible factor $1 \alpha$, HIF-1 $\alpha$; mineralocorticoid receptor, MR; mitogen-activated protein kinases, MAPKs; nitric oxide, NO; reactive oxygen species, ROS; renin angiotensin aldosterone, RAA; sphingosine kinase 1, SphK1; sphingosine-1-phosphate, S1P; transforming growth factor $\beta$, TGF- $\beta$.

Karumanchi \& Levine 2010). Another possibility to explain this epidemiological observation is the moderating effect of smoking on estrogen levels. It has been established that smoking is associated with lower circulating levels of estradiol (vs not smoking), likely contributing to related elevated risks such as osteoporosis and fragility fractures in smokers as compared to nonsmokers (Brook et al. 2012, Wong et al. 2016). Circulating estradiol levels have also been found to correlate positively with the risk of fibroid development, although this correlation is modulated by testosterone and dehydroepiandrosterone sulfate (DHEAS) levels (Wong et al. 2016). Thus, it stands to reason that the 'protective' effect of smoking on fibroid development may be due, at least in part, to a reduction in circulating estrogen, which normally acts to drive fibroid growth, although this remains to be directly demonstrated.

\section{Renin-angiotensin-aldosterone (RAA) system}

Another physiological vascular circuit that fibroids appear to 'hijack' to promote their growth is the reninangiotensin-aldosterone (RAA) system (Fig. 2). The RAA system is an evolutionarily conserved endocrinological feedback circuit involving the kidneys, lungs, liver, and vasculature that acts to increase mean arterial pressure in response to a perceived drop in circulatory volume. When the kidneys sense decreased perfusion, they release renin, an enzyme that cleaves liver-derived angiotensinogen to angiotensin-I (Ang-I), which is then converted to the bioactive ligand angiotensin-II (Ang-II) via the angiotensin-converting enzyme (ACE) in the lung. Ang-Il has direct vasoconstrictive effects on smooth muscle cells of the vasculature and stimulates the adrenal glands to produce aldosterone, a hormone 
that promotes renal tubular reabsorption of water and sodium to maintain adequate circulatory volume. Excessive activation of this pathway is thought to play a key role in the development of essential hypertension, and drugs that block components of these pathways (e.g. ACE inhibitors, ACE-I, or angiotensin receptor blockers, ARBs) are cornerstones in the treatment of essential hypertension (Te Riet et al. 2015).

Notably, aside from vascular smooth muscle cells, fibroid cells express angiotensin receptors (ATRs), and stimulation of these receptors by the ligand Ang-II induces fibroid cell proliferation, an effect that is abolished by ARBs (Isobe et al. 2008). However, whether circulating levels of Ang-II differ between patients with and without fibroids remains unknown. Extrapolating from the hypertension literature, there may not be dramatic differences in the levels of circulating Ang-II, but rather fibroid cells may be particularly sensitive to small fluctuations in local concentrations of Ang-II, perhaps due to polymorphisms in ACE or ATR genes or due to greater exposure to Ang-II over time given their blood supply (Nussberger et al. 1989, Henry et al. 2020). Indeed, polymorphisms in the ACE gene (specifically the ID and DD genotypes) have been associated with an elevated risk of fibroid (as compared to the II genotype), although whether there exists a causal link remains controversial (Gultekin et al. 2015, Keshavarzi et al. 2019). Of note, the angiotensin-II receptor $1\left(A T_{1} R\right)$ A1166C gene polymorphism, which leads to increased $\mathrm{AT}_{1} \mathrm{R}$ protein expression and has been associated with endothelial dysfunction and increased left ventricular mass, was not found to be associated with fibroid risk in a case-control study, although this is only one of a host of possible genetic variants in this receptor (Jin et al. 2012, Li et al. 2015, Keshavarzi et al. 2019). Other pathological mutations in various component proteins in the RAA system remain to be uncovered, and possible changes in Ang-II in patients with and without fibroids remain to be empirically tested.

Finally, the RAA system contains a counterbalancing arm of the circuit that may act as negative feedback on the fibroid growth. The type- 2 angiotensin-converting enzyme (ACE2) generates angiotensin 1-7 (Ang 1-7), which is a functional antagonist of Ang-Il (Casalechi et al. 2018). Ang 1-7 binds to the Mas receptor, a G protein-coupled receptor, which is present in human endometrium, and whose stimulation has antifibrotic and anti-proliferative downstream effects (Casalechi et al. 2018). Given the anatomical distribution, the Ang 1-7-Mas receptor pathway may be particularly relevant to the growth of submucosal fibroids or may be relevant to fibroid growth more generally through paracrine signaling to the myometrial tissue.

\section{Estrogen, progesterone, and pregnancy}

On the other hand, there is reason to suspect that Ang-II levels may play a role in fibroid growth through the effects of estrogen. Estrogen potently activates fibroblast proliferation in fibroids, and high estrogen states have been associated with increased fibroid size, while medications that block estrogen's production/activity can induce fibroid shrinkage (Donnez et al. 1989, Borahay et al. 2017). These effects have been attributed to direct effects of estrogen acting on fibroid cell estrogen receptors. However, estrogen also regulates transcription of angiotensinogen in the liver (Fig. 2), and thus may indirectly induce fibroid growth through upregulation of the Ang-Il precursor (Gordon et al. 1992, Krattenmacher et al. 1994). Furthermore, high estrogenic states, such as pregnancy, induce both increased Ang-Il production and increased expression of $\mathrm{AT}_{2} \mathrm{R}$ on the uterine arteries, which lead to a paradoxical increase in uterine blood flow (given Ang-II's normal vasoconstrictive effect). These effects are directly mediated through elevated estradiol levels (Mishra et al. 2018).

In addition to changes in estrogen that occur with pregnancy, progesterone elevation in pregnancy may also contribute to the regulation of fibroid growth. For instance, one study of women with fibroids undergoing in vitro fertilization (IVF) with luteal phase support with $200 \mathrm{mg}$ intravaginal progesterone found that fibroids underwent a phase of rapid growth during early pregnancy, increasing by as much as 35\% in diameter 4-5 weeks after embryo transfer, as compared to prepregnancy (Benaglia et al. 2014). While the action of several hormones or their interplay could explain this phenomenon, this rapid fibroid growth correlating with a rise in progesterone, either locally or systemically, that occurs starting in the first trimester, could partially contribute 10902789 (Luisi et al. 2000). In any case, progesterone in the experimental setting has been shown to be important for the maintenance phase of fibroid growth, an effect that is potentiated by estradiolinduced expression of progesterone receptors on fibroid cells and abrogated by the progesterone receptor blocker mifepristone (Ishikawa et al. 2010).

Fibroids' shunting of blood supply to meet their growing needs is multipronged, involving not only increased factors that promote angiogenesis/vasculogenesis but also likely via increased production of red blood cells. Case reports have described polycythemia in patients with large fibroid burden, so-called 'myomatous polycythemia,' that often resolves after myomectomy (Fig. 1), suggesting that fibroids may also recruit increased blood supply through stimulation of bone marrow production of red blood cells (Hertko 1963, Takkar \& Kumar 1994, Abdul Ghaffar et al. 2008). Possible underlying mechanisms include mass effect on the thorax leading to chronic hypoventilation or fibroid-induced vascular dysfunction leading to hypercoagulability and chronic thromboembolic disease, which can stimulate erythropoietin production (Vanden Berg \& Vasu 1963, Lacharite-Roberge et al. 2019). Again, this phenomenon is not entirely understood, and thus further research of 
novel mechanisms in which fibroids likely represent a systemic vascular disorder is necessitated.

\section{Contribution of altered vascular biology to fibroid growth}

How do all of the factors described previously lead to the growth of fibroids on a cellular level? First, we will examine how ET-1 can produce such an effect (Fig. 1). ET-1 inhibits apoptosis in multiple cell types, including fibroid cells, through its interaction with the sphingosine-1-phosphate (S1P) pathway. S1P is a bioactive sphingolipid metabolite that regulates a host of physiological and pathological processes including, pertinent to this discussion, atherosclerosis, inflammation, and tumor growth (Maceyka et al. 2012). Serum-starved rat fibroid cells (ELT3 cells) initiate apoptotic programming via the release of cytochrome C from mitochondria, caspase-3/7 activation, and DNA fragmentation (Raymond et al. 2006). The addition of ET-1 is sufficient to block this apoptosis cascade by activating sphingosine kinase 1 (SphK1), the enzyme that catalyzes the conversion of sphingosine to the bioactive form S1P (Raymond et al. 2006). Moreover, ET-1 contributes to vascular inflammation and remodeling through its interaction with hypoxia-induced factor- $1 \alpha$ (HIF-1 $\alpha$ ) (Gras et al. 2016). Whether the severely hypoxic microenvironment characteristic of fibroids induces a classic HIF- $1 \alpha$ response (i.e. leading to activation of HIF$1 \alpha$ response elements in the nucleus and target gene transcription) remains controversial, with several studies finding no changes in HIF- $1 \alpha$ expression in fibroids (although the HIF-1 system is robustly activated in leiomyosarcoma (Sadri \& Zhang 2013)). The increased HIF- $1 \alpha$ expression in fibroid cells may nevertheless lead to upregulation of several downstream genes involved in angiogenesis, including VEGFA (Mayer et al. 2008, 2010, Ishikawa et al. 2019). Whether ET-1 modulates the HIF- $1 \alpha$ pathway in response to tumor hypoxia in the case of fibroids, perhaps explaining this discrepancy, remains to be further understood.

With regard to the RAA system, Ang-II and aldosterone likely both play a direct role in stimulating fibroid growth through various intracellular signaling pathways (Fig. 1), although these effects have been more extensively studied in the cardiovascular field as compared to the fibroid field. In terms of aldosterone, fibroid cells do express mineralocorticoid receptors (MRs) and are responsive to aldosterone stimulation (Isobe et al. 2010). For instance, incubation of rat fibroid cells with aldosterone leads to a dose-dependent increase in proliferation, an effect abolished by the MR antagonists spironolactone and eplerenone (Isobe et al. 2010). In terms of intracellular signaling cascades that may be activated downstream of MRs in fibroid cells remains to be determined, but extrapolating from renal mesangial cells, it is possible that the mitogen-activated protein kinases (MAPKs) and extracellular signaling-related kinases $1 / 2$ (ERK1/2) are involved (Nishiyama et al. 2005).

In terms of Ang-II-induced changes in fibroid cellular physiology, the current state of evidence comes from a mix of cardiovascular literature and fibroid literature, as direct results from fibroids/uterine tissue are still incomplete. In cardiac myocytes, for instance, the autocrine release of Ang-II leads to loadinduced hypertrophy via transforming factor $\beta$ (TGF- $\beta$ ) (Sadoshima et al. 1993, Schultz Jel et al. 2002). TGF$\beta$, through intracellular signaling involving the SMAD protein complex, is known to play important roles not only in cell growth and survival but also in fibrosis through upregulation of extracellular matrix (ECM) deposition and remodeling (Massague \& Wotton 2000, Schiller et al. 2004, Biernacka et al. 2011). Indeed, TGF$\beta$ expression is markedly increased in fibroid smooth muscle cells as compared to normal myometrial cells and is largely responsible for orchestrating the weaving of collagens into the connective tissue that characterizes the fibroid composition (Zeyneloglu et al. 2008, Joseph et al. 2010, Borahay et al. 2015a). In addition to promoting ECM deposition, TGF- $\beta$ may also interfere with the expression of ECM-degrading genes such as matrix metalloproteinases (MMPs) (Bogusiewicz et al. 2007, Joseph et al. 2010).

Is the elevated TGF- $\beta$ signaling in fibroids restricted to the fibroid bed, or might this process be far-reaching? A recent investigation found that patients with fibroids exhibit elevated serum levels of TGF- $\beta$, which may serve as a biomarker for fibroid disease severity, in addition to potentially risk stratifying which women with fibroids may go on to develop systemic vascular complications (Kamalipooya et al. 2020). This finding is consistent with the notion that systemic dysregulation of TGF- $\beta$ signaling underlies a host of fibrotic diseases involving the vasculature, such as scleroderma, glomerulonephritis, and subclinical atherosclerosis (Malik et al. 2010, He et al. 2013). For instance, a cross-sectional case-control study found that carotid artery intima-media thickness was significantly elevated in patients with fibroids vs those without (Aksoy et al. 2014). Further, antifibrotics have been used in the experimental setting to inhibit collagen production and fibroid cell proliferation with some success, though the effects of such antifibrotics on the development of vascular disorders in patients with fibroids has not been studied (Grudzien et al. 2010).

\section{Nitric oxide (NO) signaling and endothelial dysfunction}

Nitric oxide is a free radical produced from L-arginine via nitric oxide synthase (NOS) that participates in a host of physiological processes including vasodilation and inhibition of platelet aggregation (Oh et al. 2013). Expression of eNOS in the endometrium and myometrium of patients with fibroids is significantly elevated as 
compared to those of control women, suggesting upregulation of this signaling pathway in fibroid uteri (Oh et al. 2013). Likewise, baseline NO production is elevated in culture media from fibroid cells vs that of normal myometrial cells (Favini et al. 2003). Functionally, this translates into greater oxidative stress, an effect that is exacerbated by the hypoxic microenvironment of fibroids (Fletcher et al. 2017). This increased free radical production leads to increased protein nitration and nitrosylation, which inhibits pro-apoptotic pathways and has been proposed as a means by which fibroid cells escape apoptosis (Fig. 1) (Fletcher et al. 2017).

How does aberrant NO signaling then lead to endothelial dysfunction? In general, endothelial dysfunction is characterized by proinflammatory, prothrombotic properties and a decreased propensity toward vasodilation (Endemann \& Schiffrin 2004). Vasoactive peptides such as Ang-II, ET-1, and NO modulators may contribute to this dysfunction, which can result in atherogenesis, endothelial cell apoptosis and sloughing (anoikis) (Endemann \& Schiffrin 2004). In the context of fibroids, NO-mediated oxidative stress and related endothelial dysfunction may contribute to the development of systemic hypertension and atherosclerosis in these patients (Fig. 1) (He et al. 2013, Uimari et al. 2016, Fletcher et al. 2017). In agreement, antioxidants that theoretically quench these excess free radicals have shown some clinical benefit in terms of decreasing fibroid volume, although this remains to be further explored and validated (Roshdy et al. 2013).

In summary of this section, fibroids interact extensively with the vasculature to promote their growth. In doing so, they borrow signaling pathways that work not only to regulate their local physiology but also bi-directionally with the systemic circulation, potentially promoting systemic hypertension, vascular dysfunction, and fibrosis.

\section{Approaches to treatment of fibroids that target the vasculature}

In the previous section, we explored various ways in which fibroids interact with the vasculature to promote their growth and the molecular underpinnings of these interactions. Given the demonstrated effects of fibroids on the uterine and systemic vasculature, it stands to reason that treatments targeting the vasculature may also present viable options to address fibroids.

\section{Hormonal modalities}

Traditional approaches to treating fibroids can be divided into medical vs surgical methods. Medical options have come in the form of hormonal regulation of the hypothalamic-pituitary-ovarian (HPO) axis. Hormonal management of fibroids has typically been conceptualized as directly affecting fibroid growth through estrogen and progesterone receptors on fibroid cells. For instance, combined oral contraceptive pills (OCPs), which contain formulations of estradiol and a progestin, as well as progestin-containing intrauterine devices, have been mainstays in the treatment of fibroid-related abnormal uterine bleeding, with the levonorgestrel-containing IUD showing a slightly greater reduction in fibroid-related menstrual blood loss (Sayed et al. 2011).

Gonadotropin-releasing hormone $(\mathrm{GnRH})$ agonists have also been shown to lead to fibroid shrinkage through suppression of the HPO axis via continuous receptor stimulation. Similarly, selective progesterone receptor modulators through downstream intracellular G-protein-coupled receptor signaling additionally lead to fibroid shrinkage. However, these treatments are generally limited to the preoperative setting before myomectomy or hysterectomy in order to avoid longterm side effects associated with their use (Lee et al. 2017b). Interestingly, GnRH agonists act not only to suppress the HPO axis, but relevant to the current discussion, also decrease blood flow to the uterus. This may be mediated not only through effects on estrogen and progesterone receptors on fibroid cells but also through targeting of $\mathrm{AT}_{2} \mathrm{R}$ expression on the uterine arteries (Fig. 1) (Mishra et al. 2018). This may help to explain the decreased blood loss and less need for blood transfusion associated with myomectomy in patients who receive preoperative GnRH agonists vs those who do not (Lethaby et al. 2017).

\section{Targeting RAAS}

The theoretical benefit of decreasing Ang-II signaling to treat fibroids was recently addressed in a nested casecontrol trial of women with essential hypertension. Women were divided according to whether or not they had been regularly taking an ACE-I, with the outcome of clinically recognized fibroid development across a 5 -year period (Fischer et al. 2020). Women who had been taking an ACE-I for their hypertension had 31.8\% reduced odds of subsequent fibroid development vs those not taking an ACE-I, lending credence to the idea that inhibition of the RAA system may be a novel prophylactic strategy to prevent fibroids in at-risk women. In this study, comorbidities including heart and lung disease, renal failure, liver disease, cancer, obesity, alcohol use disorder, collagen vascular diseases, and psychiatric disorders were adjusted in order to isolate the association between ACE-I use and odds of fibroid. Individual ACE-Is were studied, and several different ACE-Is were found to be associated with significantly decreased odds of fibroids, including lisinopril, quinapril, and ramipril. This study opens a line of investigation into many intriguing clinical and 
mechanistic questions. For instance, whether ACE-I use in women with pre-existing fibroids leads to fibroid shrinkage or decreased symptomatology remains to be studied. Additionally, whether antihypertensives that do not specifically target the RAAS but lower blood pressure via alternative mechanisms remains unclear. Our lab is actively working on this area of investigation, and there will likely be answers to these and other related questions in the coming years.

\section{Statins}

Apart from hormonal manipulation and RAAS targeting to decrease fibroid vascular flow and size, other strategies targeting the vasculature include the use of HMG-CoA reductase inhibitors (i.e. statins). Statins act in a pleotropic fashion by competitively blocking the rate-limiting enzyme in cholesterol synthesis (HMG-CoA reductase), preventing the conversion of HMG-CoA to mevalonic acid, and thereby lowering low-density lipoprotein cholesterol (LDL-C), and are the mainstay of treatment of dyslipidemia that can induce atherosclerosis (Ward et al. 2019). Statins act not only to decrease the accumulation of plaque on the systemic arteries by blocking LDL-c production but also have antiinflammatory properties and may improve endothelial dysfunction (Pretnar-Oblak et al. 2008, Taqueti \& Ridker 2017). Indeed, statin use is associated with a reduction in ROS and downregulation of AT1R in leukocytes of subjects with dyslipidemia (Guasti et al. 2008). A nested case-control study showed that exposure to statins within 2 years was associated with a significantly decreased odds of developing fibroids, as well as a lower likelihood of developing heavy menstrual bleeding, anemia, or pelvic pain (Borahay et al. 2016). Additional work in cell culture and animal models has demonstrated that statins cause direct caspase-3/Bim/Bcl2 mediated apoptosis and inhibition of ERK1/2, JNK, and Akt signaling in fibroid cells, similar to their effects on vascular smooth muscle cells, promoting apoptosis and stunting growth, respectively (Fig. 1) (Borahay et al. 2014, 2015b, Shen et al. 2018). Furthermore, statins were found to inhibit the deposition of excessive extracellular matrix proteins and ameliorate the altered mechanotransduction in fibroids (Malik et al. 2018, Afrin et al. 2020). Could statins also inhibit fibroid growth through effects on the uterine arteries or fibroid vascular bed? Uterine artery dysfunction occurs in the setting of an experimental model of dyslipidemia, raising the possibility that statins may also act to normalize fibroid uterine blood flow, perhaps contributing to their shrinkage or degeneration, although this remains to be tested (Taylor et al. 2003).

\section{Non-pharmacological modalities}

Finally, a non-pharmacological vascular approach to treating fibroids, short of removing the fibroids or the uterus surgically, is known as uterine artery embolization (UAE). In this procedure, the systemic arterial circulation is entered via the common femoral artery. A microcatheter is introduced, and the path of the vasculature is traced back to the uterine arteries. At this point, small (500-1000 $\mu \mathrm{m}$ diameter) polyvinyl alcohol or tris-acyl gelatin particles are fed into the uterine arteries to occlude arterial flow (Keung et al. 2018). Remarkably, uterine artery blood flow normalizes following successful UAE with shrinkage of fibroids, as measured by Doppler flow, further suggesting that fibroids act as intrinsic blood siphons within the uterus (McLucas et al. 2002).

Thus, both pharmacological and non-pharmacological treatment modalities that involve either the systemic or the local uterine vasculature have come to light as viable options for patients with fibroids. While much of this work remains experimental or preliminary, it is likely that we will see increasing efforts to decrease or reverse fibroid growth through vessel-targeting mechanisms. Conversely, it will be interesting to determine whether treatment of fibroids can also promote improvements in other associated vascular disorders such as hypertension, preeclampsia, atherosclerosis or various vasculitides.

\section{Conclusion}

Fibroids have been extensively studied over the past few decades, with significant strides made in terms of basic pathophysiology and cellular signaling. Through this work, our understanding of fibroid growth and development has become enriched, and it is increasingly clear that fibroids do not exist as an isolated entity distinct from the functioning of the rest of the human body. Indeed, in clinical studies, fibroids are often found in association with systemic diseases, especially those involving endothelial or vascular dysfunction. This newly recognized link raises interesting fundamental questions about possible causality and whether fibroids represent a uterine manifestation of a systemic disease process. Here, we have laid out the current evidence supporting the notion that fibroids are intrinsically linked to vascular biology and may in fact contribute to vascular dysfunction. This has important implications regarding the long-term health prognosis of women who have fibroids and also introduces a novel framework with which to begin to address the treatment of fibroids. It will be exciting to see how further advances in the understanding of fibroid physiology evolve over time and allow clinicians to better treat these mysterious but common benign gynecological tumors.

\section{Declaration of interest}

The authors declare that there is no conflict of interest that could be perceived as prejudicing the impartiality of this review. 


\section{Funding}

This work did not receive any specific grant from any funding agency in the public, commercial, or not-for-profit sector.

\section{Author contribution statement}

G W K and A A A wrote the initial draft of the manuscript. $M$ M-I, L R, M E S and M A B edited the draft. All authors read, edited, and approved the final draft.

\section{References}

Abdul Ghaffar NA, Ismail MP, Nik Mahmood NM, Daud K \& Abu Dzarr GA 2008 Huge uterine fibroid in a postmenopausal woman associated with polycythaemia: a case report. Maturitas 60 177-179. (https://doi.org/10.1016/j.maturitas.2008.03.013)

Afrin S, Islam MS, Patzkowsky K, Malik M, Catherino WH, Segars JH \& Borahay MA 2020 Simvastatin ameliorates altered mechanotransduction in uterine leiomyoma cells. American Journal of Obstetrics and Gynecology 223 733.e1-733.e14. (https://doi.org/10.1016/j.ajog.2020.05.012)

Agrawal R, Prelevic G, Conway GS, Payne NN, Ginsburg J \& Jacobs HS 2000 Serum vascular endothelial growth factor concentrations in postmenopausal women: the effect of hormone replacement therapy. Fertility and Sterility $\mathbf{7 3}$ 56-60. (https://doi.org/10.1016/s0015-0282(99)00476-8)

Aksoy Y, SivrI N, Karaoz B, Sayin C \& Yetkin E 2014 Carotid intima-media thickness: a new marker of patients with uterine leiomyoma. European Journal of Obstetrics, Gynecology, and Reproductive Biology 175 54-57. (https://doi.org/10.1016/j.ejogrb.2014.01.005)

AlAshqar A, Patzkowsky K, Afrin S, Wild R, Taylor HS \& Borahay MA 2019 Cardiometabolic risk factors and benign gynecologic disorders. Obstetrical and Gynecological Survey 74 661-673. (https://doi. org/10.1097/OGX.0000000000000718)

Alatas G, Aksoy E, Akarsu C, Yakin K \& Bahceci M 1997 The effect of uterine volume on uterine artery Doppler velocimetry in the myomatous state. Gynecologic and Obstetric Investigation 43 55-59. (https://doi. org/10.1159/000291820)

Aydin S, Guzel SP, Kumru S, Aydin S, Akin O, Kavak E, Sahin I, Bozkurt M \& Halifeoglu I 2008 Serum leptin and ghrelin concentrations of maternal serum, arterial and venous cord blood in healthy and preeclamptic pregnant women. Journal of Physiology and Biochemistry 64 51-59. (https://doi.org/10.1007/BF03168234)

Baban RS 2009 Serum protein and prolactin as diagnostic markers. Saudi Medical Journal 30 1411-1415.

Bacanakgil BH, Deveci M, Karabuk E \& Soyman Z 2017 Uterine smooth muscle tumor of uncertain malignant potential: clinicopathologicsonographic characteristics, follow-up and recurrence. World Journal of Oncology 8 76-80. (https://doi.org/10.14740/wjon1031w)

Bachmayer N, Rafik Hamad R, Liszka L, Bremme K \& Sverremark-Ekstrom E 2006 Aberrant uterine natural killer (NK)-cell expression and altered placental and serum levels of the NK-cell promoting cytokine interleukin-12 in pre-eclampsia. American Journal of Reproductive Immunology $\mathbf{5 6} 292$ 301. (https://doi.org/10.1111/j.1600-0897.2006.00429.x)

Baron JA 1996 Beneficial effects of nicotine and cigarette smoking: the real, the possible and the spurious. British Medical Bulletin 52 58-73. (https://doi.org/10.1093/oxfordjournals.bmb.a011533)

Basta P, Mach P, Pitynski K, Bednarek W, Klimek M, Zietek J, Zajac K \& Wicherek L 2009 Differences in the blood serum levels of soluble HLA-G concentrations between the menstrual cycle phases and menopause in patients with ovarian endometriosis and uterine leiomyoma. Neuro Endocrinology Letters 30 91-98.

Bautz F, Rafii S, Kanz L \& Mohle R 2000 Expression and secretion of vascular endothelial growth factor-A by cytokine-stimulated hematopoietic progenitor cells. Possible role in the hematopoietic microenvironment. Experimental Hematology 28 700-706. (https://doi.org/10.1016/s0301472x(00)00168-5)

Benaglia L, Cardellicchio L, Filippi F, Paffoni A, Vercellini P, Somigliana E \& Fedele L 2014 The rapid growth of fibroids during early pregnancy. PLoS ONE 9 e85933. (https://doi.org/10.1371/journal.pone.0085933)
Benditt EP \& Benditt JM 1973 Evidence for a monoclonal origin of human atherosclerotic plaques. PNAS 70 1753-1756. (https://doi.org/10.1073/ pnas.70.6.1753)

Biernacka A, Dobaczewski M \& Frangogiannis NG 2011 TGF-beta signaling in fibrosis. Growth Factors 29 196-202. (https://doi.org/10.310 9/08977194.2011.595714)

Bogusiewicz M, Stryjecka-Zimmer M, Postawski K, Jakimiuk AJ \& Rechberger T 2007 Activity of matrix metalloproteinase-2 and -9 and contents of their tissue inhibitors in uterine leiomyoma and corresponding myometrium. Gynecological Endocrinology 23 541-546. (https://doi.org/10.1080/09513590701557416)

Borahay MA, Kilic GS, Yallampalli C, Snyder RR, Hankins GD, Al-Hendy A \& Boehning D 2014 Simvastatin potently induces calcium-dependent apoptosis of human leiomyoma cells. Journal of Biological Chemistry 289 35075-35086. (https://doi.org/10.1074/jbc.M114.583575)

Borahay MA, Al-Hendy A, Kilic GS \& Boehning D 2015a Signaling pathways in leiomyoma: understanding pathobiology and implications for therapy. Molecular Medicine 21 242-256. (https://doi.org/10.2119/ molmed.2014.00053)

Borahay MA, Vincent K, Motamedi M, Sbrana E, Kilic GS, Al-Hendy A \& Boehning D 2015b Novel effects of simvastatin on uterine fibroids: in vitro and patient-derived xenograft mouse model study. American Journal of Obstetrics and Gynecology 213 196.e1-196.e8. (https://doi. org/10.1016/j.ajog.2015.03.055)

Borahay MA, Fang X, Baillargeon JG, Kilic GS, Boehning DF \& Kuo YF 2016 Statin use and uterine fibroid risk in hyperlipidemia patients: a nested case-control study. American Journal of Obstetrics and Gynecology 215 750.e1-750.e8. (https://doi.org/10.1016/j. ajog.2016.06.036)

Borahay MA, Asoglu MR, Mas A, Adam S, Kilic GS \& Al-Hendy A 2017 Estrogen receptors and signaling in fibroids: role in pathobiology and therapeutic implications. Reproductive Sciences 24 1235-1244. (https:// doi.org/10.1177/1933719116678686)

Boynton-Jarrett R, Rich-Edwards J, Malspeis S, Missmer SA \& Wright R 2005 A prospective study of hypertension and risk of uterine leiomyomata. American Journal of Epidemiology 161 628-638. (https:// doi.org/10.1093/aje/kwi072)

Brewster LM, Mairuhu G, Bindraban NR, Koopmans RP, Clark JF \& Van Montfrans GA 2006 Creatine kinase activity is associated with blood pressure. Circulation 114 2034-2039. (https://doi.org/10.1161/ CIRCULATIONAHA.105.584490)

Brook JS, Balka EB \& Zhang C 2012 The smoking patterns of women in their forties: their relationship to later osteoporosis. Psychological Reports $\mathbf{1 1 0}$ 351-362. (https://doi.org/10.2466/13.18.PR0.110.2.351-362)

Brown JM 2014 Vasculogenesis: a crucial player in the resistance of solid tumours to radiotherapy. British Journal of Radiology 8720130686. (https://doi.org/10.1259/bjr.20130686)

Bulun SE 2013 Uterine fibroids. New England Journal of Medicine 369 1344-1355. (https://doi.org/10.1056/NEJMra1209993)

Bussolino F, Wang JM, Defilippi P, Turrini F, Sanavio F, Edgell CJ, Aglietta M, Arese P \& Mantovani A 1989 Granulocyte- and granulocytemacrophage-colony stimulating factors induce human endothelial cells to migrate and proliferate. Nature 337 471-473. (https://doi. org/10.1038/337471a0)

Bussolino F, Ziche M, Wang JM, Alessi D, Morbidelli L, Cremona O, Bosia A, Marchisio PC \& Mantovani A 1991 In vitro and in vivo activation of endothelial cells by colony-stimulating factors. Journal of Clinical Investigation 87 986-995. (https://doi.org/10.1172/JCI115107)

Candido Dos Reis F, Moreira De Andrade J \& Bighetti S 2002 CA 125 and vascular endothelial growth factor in the differential diagnosis of epithelial ovarian tumors. Gynecologic and Obstetric Investigation $\mathbf{5 4}$ 132-136. (https://doi.org/10.1159/000067877)

Carmeliet P 2003 Angiogenesis in health and disease. Nature Medicine 9 653-660. (https://doi.org/10.1038/nm0603-653)

Casalechi M, Dela Cruz C, Lima LC, Maciel LP, Pereira VM \& Reis FM 2018 Angiotensin peptides in the non-gravid uterus: paracrine actions beyond circulation. Peptides 101 145-149. (https://doi.org/10.1016/j. peptides.2018.01.012)

Chen DC, Liu JY, Wu GJ, Ku CH, Su HY \& Chen CH 2005 Serum vascular endothelial growth factor165 levels and uterine fibroid volume. Acta Obstetricia et Gynecologica Scandinavica 84 317-321. (https://doi. org/10.1111/j.0001-6349.2005.00621.x) 
Chieffi P, Battista S, Barchi M, Di Agostino S, Pierantoni GM, Fedele M, Chiariotti L, Tramontano D \& Fusco A 2002 HMGA1 and HMGA2 protein expression in mouse spermatogenesis. Oncogene 21 3644-3650. (https://doi.org/10.1038/sj.onc.1205501)

Ciavattini A, Di Giuseppe J, Stortoni P, Montik N, Giannubilo SR, Litta P, Islam MS, Tranquilli AL, Reis FM \& Ciarmela P 2013 Uterine fibroids: pathogenesis and interactions with endometrium and endomyometrial junction. Obstetrics and Gynecology International 2013173184. (https://doi.org/10.1155/2013/173184)

Ciebiera M, Wlodarczyk M, Wrzosek M, Meczekalski B, Nowicka G, Lukaszuk K, Ciebiera M, Slabuszewska-Jozwiak A \& Jakiel G 2017 Role of transforming growth factor beta in uterine fibroid biology. International Journal of Molecular Sciences 18 2435. (https://doi. org/10.3390/ijms18112435)

Ciebiera M, Wlodarczyk M, Wrzosek M, Wojtyla C, Blazej M, Nowicka G, Lukaszuk K \& Jakiel G 2018a TNF-alpha serum levels are elevated in women with clinically symptomatic uterine fibroids. International Journal of Immunopathology and Pharmacology 322058738418779461. (https://doi.org/10.1177/2058738418779461)

Ciebiera M, Wlodarczyk M, Zgliczynska M, Lukaszuk K, Meczekalski B, Kobierzycki C, Lozinski T \& Jakiel G 2018b The role of tumor necrosis factor alpha in the biology of uterine fibroids and the related symptoms. International Journal of Molecular Sciences 19 3869. (https://doi. org/10.3390/ijms19123869)

Ciebiera M, Wlodarczyk M, Zgliczynski S, Lozinski T, Walczak K \& Czekierdowski A 2020 The role of miRNA and related pathways in pathophysiology of uterine fibroids-from bench to bedside. International Journal of Molecular Sciences 21 3016. (https://doi.org/10.3390/ ijms21083016)

Contini P, Negrini S, Murdaca G, Borro M \& Puppo F 2018 Evaluation of membrane-bound and soluble forms of human leucocyte antigen-G in systemic sclerosis. Clinical and Experimental Immunology 193 152-159. (https://doi.org/10.1111/cei.13134)

Cramer SF \& Patel A 1990 The frequency of uterine leiomyomas. American Journal of Clinical Pathology 94 435-438. (https://doi.org/10.1093/ ajcp/94.4.435)

Crawford BS, Davis J \& Harrigill K 1997 Uterine artery atherosclerotic disease: histologic features and clinical correlation. Obstetrics and Gynecology 90 210-215. (https://doi.org/10.1016/S0029-7844(97)00225-1)

Dahl M, Djurisic S \& Hviid TV 2014 The many faces of human leukocyte antigen-G: relevance to the fate of pregnancy. Journal of Immunology Research 2014 591489. (https://doi.org/10.1155/2014/591489)

Daly DC, Walters CA, Prior JC, Kuslis ST, Chapitis J, Andreoli J \& Riddick DH 1984 Prolactin production from proliferative phase leiomyoma. American Journal of Obstetrics and Gynecology 148 1059-1063. (https://doi.org/10.1016/s0002-9378(84)90445-9)

Delgado M \& Ganea D 2008 Anti-inflammatory neuropeptides: a new class of endogenous immunoregulatory agents. Brain, Behavior, and Immunity 22 1146-1151. (https://doi.org/10.1016/j.bbi.2008.06.001)

Demir R, Kayisli UA, Cayli S \& Huppertz B 2006 Sequential steps during vasculogenesis and angiogenesis in the very early human placenta. Placenta 27 535-539. (https://doi.org/10.1016/j.placenta.2005.05.011)

Demir R, Yaba A \& Huppertz B 2010 Vasculogenesis and angiogenesis in the endometrium during menstrual cycle and implantation. Acta Histochemica 112 203-214. (https://doi.org/10.1016/j. acthis.2009.04.004)

Donnez J, Schrurs B, Gillerot S, Sandow J \& Clerckx F 1989 Treatment of uterine fibroids with implants of gonadotropin-releasing hormone agonist: assessment by hysterography. Fertility and Sterility 51 947-950. (https://doi.org/10.1016/s0015-0282(16)60723-9)

Elkafas H, Qiwei Y \& Al-Hendy A 2017 Origin of uterine fibroids: conversion of myometrial stem cells to tumor-initiating cells. Seminars in Reproductive Medicine 35 481-486. (https://doi. org/10.1055/s-0037-1607205)

Endemann DH \& Schiffrin EL 2004 Endothelial dysfunction. Journal of the American Society of Nephrology 15 1983-1992. (https://doi. org/10.1097/01.ASN.0000132474.50966.DA)

England L \& Zhang J 2007 Smoking and risk of preeclampsia: a systematic review. Frontiers in Bioscience 12 2471-2483. (https://doi. org/10.2741/2248)

Erol O, Ellidag HY, Ayik H, Bulbul GA, Derbent AU, Kulaksizoglu S \& Yilmaz N 2016 Increased serum ghrelin in preeclampsia: is ghrelin a friend or a foe? Ginekologia Polska 87 277-282. (https://doi. org/10.17772/gp/57852)

Favini R, Aldieri E, Revelli A, Bosia A, Massobrio M \& Ghigo D 2003 Nitric oxide synthesis in human nonpregnant myometrium and uterine myomas. Fertility and Sterility 79 749-753. (https://doi.org/10.1016/ s0015-0282(02)04825-2)

Ferrara N, Houck K, Jakeman L \& Leung DW 1992 Molecular and biological properties of the vascular endothelial growth factor family of proteins. Endocrine Reviews 13 18-32. (https://doi.org/10.1210/edrv-13-1-18)

Ferrero H 2020 HMGA2 involvement in uterine leiomyomas development through angiogenesis activation. Fertility and Sterility 114 974-975. (https://doi.org/10.1016/j.fertnstert.2020.07.044)

Fischer NM, Nieuwenhuis TO, Singh B, Yenokyan G \& Segars JH 2020 Angiotensin-converting enzyme inhibitors reduce uterine fibroid incidence in hypertensive women. Journal of Clinical Endocrinology and Metabolism 106 e650-e659. (https://doi.org/10.1210/clinem/ dgaa718)

Flake GP, Andersen J \& Dixon D 2003 Etiology and pathogenesis of uterine leiomyomas: a review. Environmental Health Perspectives 111 1037-1054. (https://doi.org/10.1289/ehp.5787)

Flake GP, Moore AB, Sutton D, Kissling GE, Horton J, Wicker B, Walmer D, Robboy SJ \& Dixon D 2013 The natural history of uterine leiomyomas: light and electron microscopic studies of fibroid phases, interstitial ischemia, inanosis, and reclamation. Obstetrics and Gynecology International 2013 528376. (https://doi.org/10.1155/2013/528376)

Fletcher NM, Abusamaan MS, Memaj I, Saed MG, Al-Hendy A, Diamond MP \& Saed GM 2017 Oxidative stress: a key regulator of leiomyoma cell survival. Fertility and Sterility 107 1387.e1-1394.e1. (https://doi.org/10.1016/j.fertnstert.2017.04.015)

Gentry CC, Okolo SO, Fong LF, Crow JC, Maclean AB \& Perrett CW 2001 Quantification of vascular endothelial growth factor-A in leiomyomas and adjacent myometrium. Clinical Science 101 691-695. (https://doi. org/10.1042/CS20010096)

Gomaa SH, Zaki AM, El-Attar EA, Mokhtar MM \& Swelem MS 2015 Polymorphisms of renin angiotensin system genes in uterine leiomyomas among Egyptian females. Journal of Clinical Gynecology and Obstetrics 4 170-176. (https://doi.org/10.14740/jcgo300w)

Gordon MS, Chin WW \& Shupnik MA 1992 Regulation of angiotensinogen gene expression by estrogen. Journal of Hypertension 10 361-366. (https://doi.org/10.1097/00004872-199204000-00007)

Gras E, Belaidi E, Briancon-Marjollet A, Pepin JL, Arnaud C \& GodinRibuot D 2016 Endothelin-1 mediates intermittent hypoxia-induced inflammatory vascular remodeling through HIF-1 activation. Journal of Applied Physiology $\mathbf{1 2 0}$ 437-443. (https://doi.org/10.1152/ japplphysiol.00641.2015)

Grudzien MM, Low PS, Manning PC, Arredondo M, Belton RJ \& Nowak RA 2010 The antifibrotic drug halofuginone inhibits proliferation and collagen production by human leiomyoma and myometrial smooth muscle cells. Fertility and Sterility 93 1290-1298. (https://doi. org/10.1016/j.fertnstert.2008.11.018)

Guasti L, Marino F, Cosentino M, Maio RC, Rasini E, Ferrari M, Castiglioni L, Klersy C, Gaudio G, Grandi AM et al. 2008 Prolonged statin-associated reduction in neutrophil reactive oxygen species and angiotensin II type 1 receptor expression: 1-year follow-up. European Heart Journal 29 1118-1126. (https://doi.org/10.1093/eurheartj/ehn138)

Gultekin GI, Yilmaz SG, Kahraman OT, Atasoy H, Dalan AB, Attar R, Buyukoren A, Ucunoglu N \& Isbir T 2015 Lack of influence of the ACE1 gene $1 / D$ polymorphism on the formation and growth of benign uterine leiomyoma in Turkish patients. Asian Pacific Journal of Cancer Prevention 16 1123-1127. (https://doi.org/10.7314/apjcp.2015.16.3.1123)

Haan YC, Oudman I, De Lange ME, Timmermans A, Ankum WM, Van Montfrans GA \& Brewster LM 2015 Hypertension risk in Dutch women with symptomatic uterine fibroids. American Journal of Hypertension 28 487-492. (https://doi.org/10.1093/ajh/hpu183)

Haan YC, Diemer FS, Van Der Woude L, Van Montfrans GA, Oehlers GP \& Brewster LM 2018 The risk of hypertension and cardiovascular disease in women with uterine fibroids. Journal of Clinical Hypertension 20 718-726. (https://doi.org/10.1111/jch.13253)

Hague S, Zhang L, Oehler MK, Manek S, Mackenzie IZ, Bicknell R \& Rees MC 2000 Expression of the hypoxically regulated angiogenic factor adrenomedullin correlates with uterine leiomyoma vascular density. Clinical Cancer Research 6 2808-2814. 
Hara N, Fujii T, Yamashita T, Kozuma S, Okai T \& Taketani Y 1996 Altered expression of human leukocyte antigen G (HLA-G) on extravillous trophoblasts in preeclampsia: immunohistological demonstration with anti-HLA-G specific antibody ' $87 \mathrm{G}^{\prime}$ and anti-cytokeratin antibody 'CAM5.2'. American Journal of Reproductive Immunology 36 349-358.

Harrison-Woolrych ML, Sharkey AM, Charnock-Jones DS \& Smith SK 1995 Localization and quantification of vascular endothelial growth factor messenger ribonucleic acid in human myometrium and leiomyomata. Journal of Clinical Endocrinology and Metabolism 80 1853-1858. (https://doi.org/10.1210/jcem.80.6.7775632)

He Y, Zeng Q, Li X, Liu B \& Wang P 2013 The association between subclinical atherosclerosis and uterine fibroids. PLOS ONE 8 e57089. (https://doi.org/10.1371/journal.pone.0057089)

He C, Nelson W, Li H, Xu YD, Dai XJ, Wang YX, Ding YB, Li YP \& Li T 2021 Frequency of MED12 mutation in relation to tumor and patient's clinical characteristics: a meta-analysis. Reproductive Sciences In press. (https://doi.org/10.1007/s43032-021-00473-x)

Henry BM, Benoit S, Lippi G \& Benoit J 2020 Letter to the Editor - Circulating plasma levels of angiotensin II and aldosterone in patients with coronavirus disease 2019 (COVID-19): a preliminary report. Progress in Cardiovascular Diseases 63 702-703. (https://doi. org/10.1016/j.pcad.2020.07.006)

Hertko EJ 1963 Polycythemia (erythrocytosis) associated uterine fibroids and apparent surgical cure. American Journal of Medicine 34 288-294. (https://doi.org/10.1016/0002-9343(63)90064-0)

Hoag GN, Franks CR, Smith C \& Decoteau WE 1980 Creatine kinase isoenzyme patterns in normal smooth muscle and smooth muscle neoplasms. Clinical Biochemistry 13 149-150. (https://doi.org/10.1016/ s0009-9120(80)91027-9)

Hoekstra AV, Sefton EC, Berry E, Lu Z, Hardt J, Marsh E, Yin P, Clardy J, Chakravarti D, Bulun S et al. 2009 Progestins activate the AKT pathway in leiomyoma cells and promote survival. Journal of Clinical Endocrinology and Metabolism 94 1768-1774. (https://doi.org/10.1210/jc.2008-2093).

Holdsworth-Carson SJ, Zaitseva M, Vollenhoven BJ \& Rogers PA 2014 Clonality of smooth muscle and fibroblast cell populations isolated from human fibroid and myometrial tissues. Molecular Human Reproduction 20 250-259. (https://doi.org/10.1093/molehr/gat083)

Humphrey JD 2008 Mechanisms of arterial remodeling in hypertension: coupled roles of wall shear and intramural stress. Hypertension $\mathbf{5 2}$ 195-200. (https://doi.org/10.1161/HYPERTENSIONAHA.107.103440)

Idowu BM \& Ibitoye BO 2018 Doppler sonography of perifibroid and intrafibroid arteries of uterine leiomyomas. Obstetrics and Gynecology Science 61 395-403. (https://doi.org/10.5468/ogs.2018.61.3.395)

Ishikawa H, Ishi K, Serna VA, Kakazu R, Bulun SE \& Kurita T 2010 Progesterone is essential for maintenance and growth of uterine leiomyoma. Endocrinology 151 2433-2442. (https://doi.org/10.1210/ en.2009-1225)

Ishikawa H, Xu L, Sone K, Kobayashi T, Wang G \& Shozu M 2019 Hypoxia induces hypoxia-inducible factor 1 alpha and potential HIF-responsive gene expression in uterine leiomyoma. Reproductive Sciences 26 428-435. (https://doi.org/10.1177/1933719118776793)

Isobe A, Takeda T, Sakata M, Miyake A, Yamamoto T, Minekawa R, Nishimoto F, Oskamoto Y, Walker CL \& Kimura T 2008 Dual repressive effect of angiotensin II-type 1 receptor blocker telmisartan on angiotensin II-induced and estradiol-induced uterine leiomyoma cell proliferation. Human Reproduction 23 440-446. (https://doi.org/10.1093/humrep/ $\operatorname{dem} 247)$

Isobe A, Takeda T, Wakabayashi A, Tsuiji K, Li B, Sakata M, Yaegashi N \& Kimura T 2010 Aldosterone stimulates the proliferation of uterine leiomyoma cells. Gynecological Endocrinology 26 372-377. (https:// doi.org/10.3109/09513590903511521)

Jaffe RB 2000 Importance of angiogenesis in reproductive physiology. Seminars in Perinatology 24 79-81. (https://doi.org/10.1016/s01460005(00)80062-2)

Jin Y, Kuznetsova T, Thijs L, Schmitz B, Liu Y, Asayama K, Brand SM, Heymans S, Brand E, Fagard R et al. 2012 Association of left ventricular mass with the AGTR1 A1166C polymorphism. American Journal of Hypertension 25 472-478. (https://doi.org/10.1038/ajh.2011.244)

Jonca F, Ortega N, Gleizes PE, Bertrand N \& Plouet J 1997 Cell release of bioactive fibroblast growth factor 2 by exon 6-encoded sequence of vascular endothelial growth factor. Journal of Biological Chemistry 272 24203-24209. (https://doi.org/10.1074/jbc.272.39.24203)
Joseph DS, Malik M, Nurudeen S \& Catherino WH 2010 Myometrial cells undergo fibrotic transformation under the influence of transforming growth factor beta-3. Fertility and Sterility 93 1500-1508. (https://doi. org/10.1016/j.fertnstert.2009.01.081)

Juang CM, Yen MS, Horng HC, Twu NF, Yu HC \& Hsu WL 2006 Potential role of preoperative serum CA125 for the differential diagnosis between uterine leiomyoma and uterine leiomyosarcoma. European Journal of Gynaecological Oncology 27 370-374.

Kamalipooya S, Zarezadeh R, Latifi Z, Nouri M, Fattahi A \& Salemi Z 2020 Serum transforming growth factor beta and leucine-rich alpha2-glycoprotein 1 as potential biomarkers for diagnosis of uterine leiomyomas. Journal of Gynecology Obstetrics and Human Reproduction 50 102037. (https://doi.org/10.1016/j.jogoh.2020.102037)

Karamat FA, Oudman I, Ris-Stalpers C, Afink GB, Keijser R, Clark JF, Van Montfrans GA \& Brewster LM 2014 Resistance artery creatine kinase mRNA and blood pressure in humans. Hypertension 63 68-73. (https:// doi.org/10.1161/HYPERTENSIONAHA.113.01352)

Karumanchi SA \& Levine RJ 2010 How does smoking reduce the risk of preeclampsia? Hypertension 55 1100-1101. (https://doi.org/10.1161/ HYPERTENSIONAHA.109.148973)

Keshavarzi F, Teimoori B, Farzaneh F, Mokhtari M, Najafi D \& Salimi S 2019 Association of ACE I/D and AGTR1 A1166C gene polymorphisms and risk of uterine leiomyoma: a case-control study. Asian Pacific Journal of Cancer Prevention 20 2595-2599. (https://doi.org/10.31557/ APJCP.2019.20.9.2595)

Keung JJ, Spies JB \& Caridi TM 2018 Uterine artery embolization: a review of current concepts. Best Practice and Research: Clinical Obstetrics and Gynaecology 46 66-73. (https://doi.org/10.1016/j. bpobgyn.2017.09.003)

Kim JH, Bae KH, Byun JK, Lee S, Kim JG, Lee IK, Jung GS, Lee YM \& Park KG 2017 Lactate dehydrogenase-A is indispensable for vascular smooth muscle cell proliferation and migration. Biochemical and Biophysical Research Communications 492 41-47. (https://doi. org/10.1016/j.bbrc.2017.08.041)

Knowles J, Loizidou M \& Taylor I 2005 Endothelin-1 and angiogenesis in cancer. Current Vascular Pharmacology 3 309-314. (https://doi. org/10.2174/157016105774329462)

Koukourakis MI, Kontomanolis E, Giatromanolaki A, Sivridis E \& Liberis V 2009 Serum and tissue LDH levels in patients with breast/gynaecological cancer and benign diseases. Gynecologic and Obstetric Investigation 67 162-168. (https://doi.org/10.1159/000183250)

Krattenmacher R, Knauthe R, Parczyk K, Walker A, Hilgenfeldt U \& Fritzemeier KH 1994 Estrogen action on hepatic synthesis of angiotensinogen and IGF-I: direct and indirect estrogen effects. Journal of Steroid Biochemistry and Molecular Biology 48 207-214. (https://doi. org/10.1016/0960-0760(94)90146-5)

Kurjak A, Kupesic-Urek S \& Miric D 1992 The assessment of benign uterine tumor vascularization by transvaginal color Doppler. Ultrasound in Medicine and Biology 18 645-649. (https://doi.org/10.1016/03015629(92)90079-p)

Kuwahara F, Kai H, Tokuda K, Kai M, Takeshita A, Egashira K \& Imaizumi T 2002 Transforming growth factor-beta function blocking prevents myocardial fibrosis and diastolic dysfunction in pressureoverloaded rats. Circulation 106 130-135. (https://doi.org/10.1161/01. cir.0000020689.12472.e0)

Lacharite-Roberge AS, Raza F, Bashir R, Dass CA, Moser GW, Auger WR, Toyoda Y, Forfia PR \& Vaidya A 2019 Case series of seven women with uterine fibroids associated with venous thromboembolism and chronic thromboembolic disease. Pulmonary Circulation 92045894018803873. (https://doi.org/10.1177/2045894018803873)

Lash GE \& Bulmer JN 2011 Do uterine natural killer (UNK) cells contribute to female reproductive disorders? Journal of Reproductive Immunology 88 156-164. (https://doi.org/10.1016/j.jri.2011.01.003)

Laughlin-Tommaso SK, Fuchs EL, Wellons MF, Lewis CE, CalderonMargalit R, Stewart EA \& Schreiner PJ 2019 Uterine fibroids and the risk of cardiovascular disease in the coronary artery risk development in young adult women's study. Journal of Women's Health 28 46-52. (https://doi.org/10.1089/jwh.2018.7122)

Lawicki S, Bedkowska GE, Gacuta-Szumarska E, Czygier M \& Szmitkowski PJ 2010 The plasma levels and diagnostic utility of selected hematopoietic growth factors in endometrial cancer patients and with myoma uteri. Polski Merkuriusz Lekarski 28 354-358. 
Lee J, Lee S, Zhang H, Hill MA, Zhang C \& Park Y 2017a Interaction of IL-6 and TNF-alpha contributes to endothelial dysfunction in type 2 diabetic mouse hearts. PLOS ONE 12 e0187189. (https://doi.org/10.1371/journal. pone.0187189)

Lee MJ, Yun BS, Seong SJ, Kim ML, Jung YW, Kim MK, Bae HS, Kim DH \& Hwang JY 2017b Uterine fibroid shrinkage after short-term use of selective progesterone receptor modulator or gonadotropin-releasing hormone agonist. Obstetrics and Gynecology Science 60 69-73. (https:// doi.org/10.5468/ogs.2017.60.1.69)

Lethaby A, Puscasiu L \& Vollenhoven B 2017 Preoperative medical therapy before surgery for uterine fibroids. Cochrane Database of Systematic Reviews 11 CD000547. (https://doi.org/10.1002/14651858.CD000547. pub2)

Levy G, Hill MJ, Plowden TC, Catherino WH \& Armstrong AY 2013 Biomarkers in uterine leiomyoma. Fertility and Sterility 99 1146-1152. (https://doi.org/10.1016/j.fertnstert.2012.10.048)

Li Y, Chen F, Zhang X, Gao Y, Wu C, Li H \& Zhang Y 2015 Angiotensin type 1 receptor $\mathrm{A} 1166 \mathrm{C}$ gene polymorphism is associated with endothelial dysfunction and in-stent restenosis after percutaneous coronary intervention. International Journal of Clinical and Experimental Pathology 8 7350-7357.

Li Y, Qiang W, Griffin BB, Gao T, Chakravarti D, Bulun S, Kim JJ \& Wei JJ 2020 HMGA2-mediated tumorigenesis through angiogenesis in leiomyoma. Fertility and Sterility 114 1085-1096. (https://doi. org/10.1016/j.fertnstert.2020.05.036)

Luisi S, Petraglia F, Benedetto C, Nappi RE, Bernardi F, Fadalti M, Reis FM, Luisi M \& Genazzani AR 2000 Serum allopregnanolone levels in pregnant women: changes during pregnancy, at delivery, and in hypertensive patients. Journal of Clinical Endocrinology and Metabolism 85 2429-2433. (https://doi.org/10.1210/jcem.85.7.6675)

Luo N, Guan Q, Zheng L, Qu X, Dai H \& Cheng Z 2014 Estrogen-mediated activation of fibroblasts and its effects on the fibroid cell proliferation. Translational Research 163 232-241. (https://doi.org/10.1016/j. trsl.2013.11.008)

Luoto R, Rutanen EM \& Auvinen A 2001 Fibroids and hypertension. A cross-sectional study of women undergoing hysterectomy. Journal of Reproductive Medicine 46 359-364.

Maceyka M, Harikumar KB, Milstien S \& Spiegel S 2012 Sphingosine-1phosphate signaling and its role in disease. Trends in Cell Biology 22 50-60. (https://doi.org/10.1016/j.tcb.2011.09.003)

Makinen N, Mehine M, Tolvanen J, Kaasinen E, Li Y, Lehtonen HJ, Gentile M, Yan J, Enge M, Taipale $\mathbf{M}$ et al. 2011 MED12, the mediator complex subunit 12 gene, is mutated at high frequency in uterine leiomyomas. Science 334 252-255. (https://doi.org/10.1126/ science.1208930)

Malik M, Norian J, Mccarthy-Keith D, Britten J \& Catherino WH 2010 Why leiomyomas are called fibroids: the central role of extracellular matrix in symptomatic women. Seminars in Reproductive Medicine 28 169-179. (https://doi.org/10.1055/s-0030-1251475)

Malik M, Britten J, Borahay M, Segars J \& Catherino WH 2018 Simvastatin, at clinically relevant concentrations, affects human uterine leiomyoma growth and extracellular matrix production. Fertility and Sterility $\mathbf{1 1 0}$ 1398-1407.e1. (https://doi.org/10.1016/j.fertnstert.2018.07.024)

Markowska A, Ziolkowska A, Nowinka K \& Malendowicz LK 2009 Elevated blood active ghrelin and normal total ghrelin and obestatin concentrations in uterine leiomyoma. European Journal of Gynaecological Oncology 30 281-284.

Massague J \& Wotton D 2000 Transcriptional control by the TGF-beta/ Smad signaling system. EMBO Journal 19 1745-1754. (https://doi. org/10.1093/emboj/19.8.1745)

Mayer A, Hockel M, Wree A, Leo C, Horn LC \& Vaupel P 2008 Lack of hypoxic response in uterine leiomyomas despite severe tissue hypoxia. Cancer Research 68 4719-4726. (https://doi.org/10.1158/0008-5472. CAN-07-6339)

Mayer A, Hoeckel M, Von Wallbrunn A, Horn LC, Wree A \& Vaupel P 2010 HIF-mediated hypoxic response is missing in severely hypoxic uterine leiomyomas. Advances in Experimental Medicine and Biology 662 399-405. (https://doi.org/10.1007/978-1-4419-1241-1_58)

McLucas B, Perrella R, Goodwin S, Adler L \& Dalrymple J 2002 Role of uterine artery Doppler flow in fibroid embolization. Journal of Ultrasound in Medicine 21 113-120. (https://doi.org/10.7863/ jum.2002.21.2.113)
McWilliams MM \& Chennathukuzhi VM 2017 Recent advances in uterine fibroid etiology. Seminars in Reproductive Medicine 35 181-189. (https://doi.org/10.1055/s-0037-1599090)

Medeiros F, Erickson-Johnson MR, Keeney GL, Clayton AC, Nascimento AG, Wang X \& Oliveira AM 2007 Frequency and characterization of HMGA2 and HMGA1 rearrangements in mesenchymal tumors of the lower genital tract. Genes, Chromosomes and Cancer 46 981-990. (https://doi. org/10.1002/gcc.20483)

Mesquita FS, Dyer SN, Heinrich DA, Bulun SE, Marsh EE \& Nowak RA 2010 Reactive oxygen species mediate mitogenic growth factor signaling pathways in human leiomyoma smooth muscle cells. Biology of Reproduction $\mathbf{8 2}$ 341-351. (https://doi.org/10.1095/ biolreprod.108.075887)

Mishra JS, Gopalakrishnan K \& Kumar S 2018 Pregnancy upregulates angiotensin type 2 receptor expression and increases blood flow in uterine arteries of rats. Biology of Reproduction 99 1091-1099. (https:// doi.org/10.1093/biolre/ioy130)

Moridi I, Mamillapalli R, Kodaman PH, Habata S, Dang T \& Taylor HS 2020 CXCL12 attracts bone marrow-derived cells to uterine leiomyomas. Reproductive Sciences 27 1724-1730. (https://doi.org/10.1007/s43032020-00166-x)

Moss NS \& Benditt EP 1975 Human atherosclerotic plaque cells and leiomyoma cells. Comparison of in vitro growth characteristics. American Journal of Pathology 78 175-190.

Nair S \& Al-Hendy A 2011 Adipocytes enhance the proliferation of human leiomyoma cells via TNF- $\alpha$ proinflammatory cytokine. Reproductive Sciences 18 1186-1192. (https://doi.org/10.1177/1933719111408111)

Nezhad MH, Drieschner N, Helms S, Meyer A, Tadayyon M, Klemke M, Belge G, Bartnitzke S, Burchardt K, Frantzen C et al. 2010 6p21 rearrangements in uterine leiomyomas targeting HMGA1. Cancer Genetics and Cytogenetics 203 247-252. (https://doi.org/10.1016/j. cancergencyto.2010.08.005)

Nishiyama A, Yao L, Fan Y, Kyaw M, Kataoka N, Hashimoto K, Nagai Y, Nakamura E, Yoshizumi M, Shokoji T et al. 2005 Involvement of aldosterone and mineralocorticoid receptors in rat mesangial cell proliferation and deformability. Hypertension 45 710-716. (https://doi. org/10.1161/01.HYP.0000154681.38944.9a)

Nowak RA, Mora S, Diehl T, Rhoades AR \& Stewart EA 1999 Prolactin is an autocrine or paracrine growth factor for human myometrial and leiomyoma cells. Gynecologic and Obstetric Investigation 48 127-132. (https://doi.org/10.1159/000010154)

Nussberger J, Waeber B \& Brunner HR 1989 Plasma angiotensin II and the antihypertensive action of angiotensin-converting enzyme inhibition. American Journal of Hypertension 2 286-293. (https://doi.org/10.1093/ ajh/2.4.286)

O'Brien M, Earley P, Morrison JJ \& Smith TJ 2010 Ghrelin in the human myometrium. Reproductive Biology and Endocrinology 8 55. (https://doi. org/10.1186/1477-7827-8-55)

Oh NJ, Ryu KY, Jung CN, Yi SY \& Kim SR 2013 Expression of endothelial nitric oxide synthase in the uterus of patients with leiomyoma or adenomyosis. Journal of Obstetrics and Gynaecology Research 39 536-542. (https://doi.org/10.1111/j.1447-0756.2012.01980.x)

Okolo S 2008 Incidence, aetiology and epidemiology of uterine fibroids. Best Practice and Research: Clinical Obstetrics and Gynaecology 22 571-588. (https://doi.org/10.1016/j.bpobgyn.2008.04.002)

Pan L, Fu Z, Yin P \& Chen D 2019 Pre-existing medical disorders as risk factors for preeclampsia: an exploratory case-control study. Hypertension in Pregnancy 38 245-251. (https://doi.org/10.1080/10641955.2019.166 7381)

Parazzini F, Negri E, La Vecchia C, Rabaiotti M, Luchini L, Villa A \& Fedele L 1996 Uterine myomas and smoking. Results from an Italian study. Journal of Reproductive Medicine 41 316-320.

Pelage JP, Cazejust J, Pluot E, Le Dref O, Laurent A, Spies JB, Chagnon S \& Lacombe P 2005 Uterine fibroid vascularization and clinical relevance to uterine fibroid embolization. RadioGraphics 25 S99-S117. (https:// doi.org/10.1148/rg.25si055510)

Picchi A, Gao X, Belmadani S, Potter BJ, Focardi M, Chilian WM \& Zhang C 2006 Tumor necrosis factor-alpha induces endothelial dysfunction in the prediabetic metabolic syndrome. Circulation Research 99 69-77. (https://doi.org/10.1161/01.RES.0000229685.37402.80)

Possomato-Vieira JS \& Khalil RA 2016 Mechanisms of endothelial dysfunction in hypertensive pregnancy and preeclampsia. 
Advances in Pharmacology 77 361-431. (https://doi.org/10.1016/ bs.apha.2016.04.008)

Pretnar-Oblak J, Sebestjen M \& Sabovic M 2008 Statin treatment improves cerebral more than systemic endothelial dysfunction in patients with arterial hypertension. American Journal of Hypertension 21 674-678. (https://doi.org/10.1038/ajh.2008.153)

Quenby S, Nik H, Innes B, Lash G, Turner M, Drury J \& Bulmer J 2009 Uterine natural killer cells and angiogenesis in recurrent reproductive failure. Human Reproduction 24 45-54. (https://doi.org/10.1093/humrep/den348)

Radin RG, Rosenberg L, Palmer JR, Cozier YC, Kumanyika SK \& Wise LA 2012 Hypertension and risk of uterine leiomyomata in US black women. Human Reproduction 27 1504-1509. (https://doi.org/10.1093/humrep/ des046)

Raymond MN, Bole-Feysot C, Banno Y, Tanfin Z \& Robin P 2006 Endothelin-1 inhibits apoptosis through a sphingosine kinase 1-dependent mechanism in uterine leiomyoma ELT3 cells. Endocrinology 147 5873-5882. (https://doi.org/10.1210/en.2006-0291)

Rein MS, Friedman AJ \& Heffner LJ 1990 Decreased prolactin secretion by explant cultures of fibroids from women treated with a gonadotropinreleasing hormone agonist. Journal of Clinical Endocrinology and Metabolism 70 1554-1558. (https://doi.org/10.1210/jcem-70-6-1554)

Ribatti D \& Tamma R 2019 Hematopoietic growth factors and tumor angiogenesis. Cancer Letters 440-441 47-53. (https://doi.org/10.1016/j. canlet.2018.10.008)

Roberts WE, Fulp KS, Morrison JC \& Martin JN 1999 The impact of leiomyomas on pregnancy. Australian and New Zealand Journal of Obstetrics and Gynaecology 39 43-47. (https://doi.org/10.1111/j.1479828x.1999.tb03442.x)

Roshdy E, Rajaratnam V, Maitra S, Sabry M, Allah AS \& Al-Hendy A 2013 Treatment of symptomatic uterine fibroids with green tea extract: a pilot randomized controlled clinical study. International Journal of Women's Health 5 477-486. (https://doi.org/10.2147/JJWH.S41021)

Sadoshima J, Xu Y, Slayter HS \& Izumo S 1993 Autocrine release of angiotensin II mediates stretch-induced hypertrophy of cardiac myocytes in vitro. Cell 75 977-984. (https://doi.org/10.1016/00928674(93)90541-w)

Sadri N \& Zhang PJ 2013 Hypoxia-inducible factors: mediators of cancer progression; prognostic and therapeutic targets in soft tissue sarcomas. Cancers 5 320-333. (https://doi.org/10.3390/cancers5020320)

Saleh L, Verdonk K, Visser W, Van Den Meiracker AH \& Danser AH 2016 The emerging role of endothelin-1 in the pathogenesis of pre-eclampsia. Therapeutic Advances in Cardiovascular Disease 10 282-293. (https:// doi.org/10.1177/1753944715624853)

Sang GY, Chen ZY, Meng CR, Tian T \& Zhang ZX 2018 Serum tumor marker carbohydrate antigen 125 levels and carotid atherosclerosis in patients with coronary artery disease. Open Medicine 13 534-538. (https://doi. org/10.1515/med-2018-0078)

Sauro MD \& Zorn NE 1991 Prolactin induces proliferation of vascular smooth muscle cells through a protein kinase C-dependent mechanism. Journal of Cellular Physiology 148 133-138. (https://doi.org/10.1002/ jcp.1041480116)

Sayed GH, Zakherah MS, El-Nashar SA \& Shaaban MM 2011 A randomized clinical trial of a levonorgestrel-releasing intrauterine system and a lowdose combined oral contraceptive for fibroid-related menorrhagia. International Journal of Gynaecology and Obstetrics 112 126-130. (https://doi.org/10.1016/j.ijgo.2010.08.009)

Schiller M, Javelaud D \& Mauviel A 2004 TGF-beta-induced SMAD signaling and gene regulation: consequences for extracellular matrix remodeling and wound healing. Journal of Dermatological Science 35 83-92. (https://doi.org/10.1016/j.jdermsci.2003.12.006)

Schultz Jel J, Witt SA, Glascock BJ, Nieman ML, Reiser PJ, Nix SL, Kimball TR \& Doetschman T 2002 TGF-beta1 mediates the hypertrophic cardiomyocyte growth induced by angiotensin II. Journal of Clinical Investigation 109 787-796. (https://doi.org/10.1172/JCI14190)

Shahid R, Abbas H, Mumtaz S, Perveen F, Bari MF, Raja T, Memon S, Ahmed N \& Dawani K 2020 Hysterectomy and oophorectomy in reproductive age: A cross-sectional study from a tertiary Care Hospital. Cureus 12 e8344. (https://doi.org/10.7759/cureus.8344)

Shen Z, Li S, Sheng B, Shen Q, Sun LZ, Zhu H \& Zhu X 2018 The role of atorvastatin in suppressing tumor growth of uterine fibroids. Journal of Translational Medicine 16 53. (https://doi.org/10.1186/s12967-018-1430-x)
Shimizu H, Hirose Y, Nishijima F, Tsubakihara Y \& Miyazaki H 2009 ROS and PDGF-beta [corrected] receptors are critically involved in indoxyl sulfate actions that promote vascular smooth muscle cell proliferation and migration. American Journal of Physiology: Cell Physiology 297 C389-C396. (https://doi.org/10.1152/ajpcell.00206.2009)

Song KJ, Yu XN, Lv T, Chen YL, Diao YC, Liu SL, Wang YK \& Yao Q 2018 Expression and prognostic value of lactate dehydrogenase-A and -D subunits in human uterine myoma and uterine sarcoma. Medicine $\mathbf{9 7}$ e0268. (https://doi.org/10.1097/MD.0000000000010268)

Stewart EA, Laughlin-Tommaso SK, Catherino WH, Lalitkumar S, Gupta D \& Vollenhoven B 2016 Uterine fibroids. Nature Reviews: Disease Primers 2 16043. (https://doi.org/10.1038/nrdp.2016.43)

Stewart EA, Cookson CL, Gandolfo RA \& Schulze-Rath R 2017 Epidemiology of uterine fibroids: a systematic review. BJOG 124 1501-1512. (https://doi.org/10.1111/1471-0528.14640)

Takkar D \& Kumar A 1994 Polycythemia associated with uterine fibroid. Indian Journal of Medical Sciences 48 144-146.

Tal R \& Segars JH 2014 The role of angiogenic factors in fibroid pathogenesis: potential implications for future therapy. Human Reproduction Update 20 194-216. (https://doi.org/10.1093/humupd/ $\mathrm{dmt} 042)$

Tal R, Dong D, Shaikh S, Mamillapalli R \& Taylor HS 2019 Bone-marrowderived endothelial progenitor cells contribute to vasculogenesis of pregnant mouse uterusdagger. Biology of Reproduction 100 1228-1237. (https://doi.org/10.1093/biolre/ioy265)

Taqueti VR \& Ridker PM 2017 Lipid-lowering and anti-inflammatory benefits of statin therapy: more than meets the plaque. Circulation: Cardiovascular Imaging $\mathbf{1 0}$ e006676. (https://doi.org/10.1161/ CIRCIMAGING.117.006676)

Taylor PD, Khan IY, Lakasing L, Dekou V, O'Brien-Coker I, Mallet AI, Hanson MA \& Poston L 2003 Uterine artery function in pregnant rats fed a diet supplemented with animal lard. Experimental Physiology $\mathbf{8 8}$ 389-398. (https://doi.org/10.1113/eph8802495)

Te Riet L, Van Esch JH, Roks AJ, Van Den Meiracker AH \& Danser AH 2015 Hypertension: renin-angiotensin-aldosterone system alterations. Circulation Research 116 960-975. (https://doi.org/10.1161/ CIRCRESAHA.116.303587)

Templeman C, Marshall SF, Clarke CA, Delellis Henderson K, Largent J, Neuhausen S, Reynolds P, Ursin G \& Bernstein L 2009 Risk factors for surgically removed fibroids in a large cohort of teachers. Fertility and Sterility 92 1436-1446. (https://doi.org/10.1016/j. fertnstert.2008.08.074)

Torry DS, Holt VJ, Keenan JA, Harris G, Caudle MR \& Torry RJ 1996 Vascular endothelial growth factor expression in cycling human endometrium. Fertility and Sterility 66 72-80. (https://doi.org/10.1016/ S0015-0282(16)58390-3)

Tseng J] \& Chou MM 2006 Differential expression of growth-, angiogenesisand invasion-related factors in the development of placenta accreta. Taiwanese Journal of Obstetrics and Gynecology 45 100-106. (https:// doi.org/10.1016/S1028-4559(09)60205-9)

Uimari O, Auvinen J, Jokelainen J, Puukka K, Ruokonen A, Jarvelin MR, Piltonen T, Keinanen-Kiukaanniemi S, Zondervan K, Jarvela I et al. 2016 Uterine fibroids and cardiovascular risk. Human Reproduction 31 2689-2703. (https://doi.org/10.1093/humrep/dew249)

Vanden Berg AR \& Vasu CM 1963 Polycythemia associated with uterine fibroma. JAMA 185 249-251 (https://doi.org/10.1001/ jama.1963.03060040033016).

Wallace K, Chatman K, Porter J, Scott J, Johnson V, Moseley J \& Lamarca B 2014 Enodthelin 1 is elevated in plasma and explants from patients having uterine leiomyomas. Reproductive Sciences 21 1196-1205. (https://doi.org/10.1177/1933719114542018)

Wallace K, Chatman K, Johnson V, Brookins A, Rushing J \& Lamarca B 2018 Novel treatment avenues for uterine leiomyoma: a new implication for endothelin? Clinical Science 132 2261-2267. (https://doi.org/10.1042/ CS20180474)

Walters CA, Daly DC, Chapitis J, Kuslis ST, Prior JC, Kusmik WF \& Riddick DH 1983 Human myometrium: a new potential source of prolactin. American Journal of Obstetrics and Gynecology 147 639-644. (https://doi.org/10.1016/0002-9378(83)90441-6)

Ward NC, Watts GF \& Eckel RH 2019 Statin toxicity. Circulation Research 124 328-350. (https://doi.org/10.1161/CIRCRESAHA.118.312782) 
Watanabe K \& Suzuki T 2006 Uterine leiomyoma versus leiomyosarcoma: a new attempt at differential diagnosis based on their cellular characteristics. Histopathology 48 563-568. (https://doi.org/10.1111/ j.1365-2559.2006.02368.x)

Wechter ME, Stewart EA, Myers ER, Kho RM \& Wu JM 2011 Leiomyomarelated hospitalization and surgery: prevalence and predicted growth based on population trends. American Journal of Obstetrics and Gynecology 205 492.e1-492.e5. (https://doi.org/10.1016/j. ajog.2011.07.008)

Wise LA \& Laughlin-Tommaso SK 2016 Epidemiology of uterine fibroids: from menarche to menopause. Clinical Obstetrics and Gynecology 59 2-24. (https://doi.org/10.1097/GRF.0000000000000164)

Wong JY, Gold EB, Johnson WO \& Lee JS 2016 Circulating sex hormones and risk of uterine fibroids: study of women's health across the nation (swan). Journal of Clinical Endocrinology and Metabolism 101 123-130. (https://doi.org/10.1210/jc.2015-2935)

Yamada H, Sata F, Kato EH, Saijo Y, Kataoka S, Morikawa M, Shimada S, Yamada T, Kishi R \& Minakami H 2004 A polymorphism in the CYP17 gene and intrauterine fetal growth restriction. Molecular Human Reproduction 10 49-53. (https://doi.org/10.1093/molehr/gah005)

Zaniolo K, Sapieha P, Shao Z, Stahl A, Zhu T, Tremblay S, Picard E, Madaan A, Blais M, Lachapelle P et al. 2011 Ghrelin modulates physiologic and pathologic retinal angiogenesis through GHSR-1a. Investigative Ophthalmology and Visual Science 52 5376-5386. (https:// doi.org/10.1167/iovs.10-7152)

Zepiridis LI, Grimbizis GF \& Tarlatzis BC 2016 Infertility and uterine fibroids. Best Practice and Research: Clinical Obstetrics and Gynaecology 34 66-73. (https://doi.org/10.1016/j.bpobgyn.2015.12.001)
Zeyneloglu HB, Esinler I, Ozdemir BH, Haydardedeoglu B, Oktem M \& Batioglu S 2008 Immunohistochemical characteristics of intramural leiomyomata that enlarge during controlled ovarian hyperstimulation for in vitro fertilization. Gynecologic and Obstetric Investigation 65 252-257. (https://doi.org/10.1159/000113049)

Zhang H, Park Y, Wu J, Chen Xp, Lee S, Yang J, Dellsperger KC \& Zhang C 2009 Role of TNF-alpha in vascular dysfunction. Clinical Science $\mathbf{1 1 6}$ 219-230. (https://doi.org/10.1042/CS20080196)

Zhang G, Yin X, Qi Y, Pendyala L, Chen J, Hou D \& Tang C 2010 Ghrelin and cardiovascular diseases. Current Cardiology Reviews 6 62-70. (https://doi.org/10.2174/157340310790231662)

Zimmermann A, Bernuit D, Gerlinger C, Schaefers M \& Geppert K 2012 Prevalence, symptoms and management of uterine fibroids: an international internet-based survey of 21,746 women. BMC Women's Health 12 6. (https://doi.org/10.1186/1472-6874-12-6)

Zygmunt M, Herr F, Munstedt K, Lang U \& Liang OD 2003 Angiogenesis and vasculogenesis in pregnancy. European Journal of Obstetrics, Gynecology, and Reproductive Biology 110 S10-S18. (https://doi. org/10.1016/s0301-2115(03)00168-4)

Received 28 February 2021

First decision 7 April 2021

Revised manuscript received 20 May 2021

Accepted 25 May 2021 